\title{
Magma accumulation and segregation during regional-scale folding: the Holland's dome granite injection complex, Damara belt, Namibia.
}

\author{
by
}

Tolene Mia Kruger

\author{
Thesis presented in fulfilment of the requirements for the degree of \\ Master of Science in the Faculty of Science at \\ Stellenbosch University
}

Supervisor:

Prof. Alexander F.M. Kisters

Department of Earth Sciences

Stellenbosch University

December 2016 


\section{Declaration}

By submitting this thesis electronically, I declare that the entirety of the work contained herein is my own, original work, that I am the sole author thereof (save to the extent explicitly otherwise stated), that reproduction and publication thereof by Stellenbosch University will not infringe any third party rights and that I have not previously in its entirety or in part submitted it for obtaining any qualification.

Tolene Mia Kruger

Date: December 2016

Copyright @ 2016 Stellenbosch University

All rights reserved 


\section{Abstract}

Mid-crustal, upper amphibolite-facies rocks in the south Central Zone magmatic arc of the Damara belt in central Namibia contain kilometre-scale networks of intrusive, sheet-like leucogranites. These granite injection complexes are spatially and temporally closely associated with regional folds, particularly antiformal structures, and document the presence and geometries of magma permeability networks in suprasolidus ( $\left.\mathrm{T} \sim 700-750{ }^{\circ} \mathrm{C}, \mathrm{P} \sim 5 \mathrm{kbar}\right)$ crust, close to the anatectic zone. The Holland's dome is a northeast-trending, upright, isoclinal, gently doubly plunging antiform that formed during northwest-southeast shortening in supracrustal rocks above the basement-cover contact in the south Central Zone. Highly fractionated leucogranite sheets have intruded the Holland's dome as three main orthogonal sets. The predominant set of subvertical granite sheets is roughly axial planar to the fold dome and is intersected at right angles by a subvertical and subhorizontal set of leucogranites normal to the fold axial plane. Contacts between the three main sets are mostly continuous pointing to the broadly coeval emplacement of leucogranites, while the internal sheeting of granites documents the incremental growth of larger granite sheets through successively injected smaller magma batches. The granites constitute between $40-80 \%$ of the outcrop area, but wallrock fragments have undergone little or no rotation with little evidence for a whole-scale flow and disruption of the succession. All three leucogranite sets cross-cut subvertical wall rocks. This underlines the late-kinematic emplacement of the granite sets during fold lock-up and flattening of the fold.

Structural relationships between leucogranite sheets and the Holland's dome point to a stepwise evolution of the injection complex during folding from (1) the dilatancy-driven segregation and accumulation of granitic magmas in the core of the fold during fold amplification above the basement-cover detachment, followed by (2) fold tightening and 
compaction-driven segregation of a melt from the initially accumulated magma in the core of the fold. This stage corresponds to the formation of the injection complex at the present-day erosional level of the Holland's dome. The successive assembly of the granite network through the injection of probably thousands of smaller melt batches ensures compatibility between regional strain rates during fold amplification and the rates of magma segregation and emplacement. The orientation of sheets closely reflects the regional stress field and folding of the cover sequence during regional shortening. Strain localization associated with the late-stage injection of a three-dimensional melt network also facilitates tightening of the Holland's dome beyond the fold lock-up stage during ongoing regional shortening. Granite injection complexes similar to that of the Holland's dome are common in the mid-crust of the Damara belt. The presence of the injection complexes highlights the significance of regional-scale folding for the formation of temporary magma accumulation sites and the redistribution of progressively more fractionated melts during deformation in suprasolidus crust. 


\section{Opsomming}

Middel-aardkors, boonste-amfiboliet fasies gesteentes in die suid-Sentrale Sone magmatiese boog van die Damara gordel in sentraal Namibië bevat kilometer-skaalse netwerke van intrusiewe, leukograniet plate. Hierdie graniet injeksiekomplekse is ruimtelik en tydelik nou verwant aan regionale plooie, spesifiek antiforme strukture, en dokumenteer die teenwoordigheid en geometrie van magma deurlatendheid netwerke in bo-solidus ( $\mathrm{T} \sim 700-750$ ${ }^{\circ} \mathrm{C}, \mathrm{P} \sim 5$ kbar) aardkors, naby aan die anatektiese sone. Die Holland's koepel is 'n noordoosstrekkende, regop, isoklinale, liggies dubbel-duikende plooi wat tydens noordwes-suidoos verkorting van die bokorsgesteentes gevorm het bo die vloer-bedekkingsgesteente kontak in die suid-Sentral Sone. Hoogs gefraksioneerde leukograniet plate het die Holland's koepel ingedring en vorm drie ortogonale stelle. Die dominante stel van subvertikale plate is asvlakplanêr met die koepel en word reghoekig gesny deur 'n subvertikale en subhorisontale stel van leukograniete loodreg teenoor die plooi se asvlak. Kontakte tussen die drie hoof plaatstelle is meestal deurlopend en verwys na die gelyktydige inplasing van leukograniete, terwyl die interne plaatvorming van graniete die inkrementele groei van groter plate deur middel van agtereenvolgende injeksie van kleiner magma hoeveelhede dokumenteer. Die graniet maak tussen 40-80 \% van die dagsoomarea op, maar wandgesteente fragmente het minimale of geen rotasie ondergaan nie, met amper geen bewyse van ' $n$ heelskaalse vloei en ontwrigting van die suksessie nie. Al drie leukograniet stelle kruissny subvertikale wandgesteentes. Dit beklemtoon die laat-kinematiese inplasing van die graniet stelle tydens plooisluiting en afplatting van die plooi.

Strukturele verhoudings tussen die leukograniet plate en die Holland's koepel dui op die stapgewyse evolusie van die injeksiekompleks tydens plooiing vanaf (1) die dilatantegedrewe segregasie en akkumulasie van granietiese magmas in die kern van die plooi 
gedurende plooi versterking bo die vloer-bedekkingsgesteente afstropingsvlak, gevolg deur (2) plooi vernouing en kompaksiegedrewe segregasie van 'n smeltsel van die aanvanklik geakkumuleerde magma in die kern van die plooi. Hierdie stadium korrespondeer met die vorming van die injeksiekompleks in die hedendaagse verweringsvlak van die Holland's koepel. Die agtereenvolgende samestelling van die granietnetwerk deur middel van die injeksie van seker duisende kleiner smeltsel hoeveelhede verseker die verenigbaarheid tussen regionale vervormings tempo gedurende plooi versterking en die tempo van magma segregasie en inplasing. Die orientasie van plate reflekteer die streeksstresveld en die plooiing van die bedekkingsgesteentesuksessie gedurende regionale verkorting. Spannings lokalisering verwant aan die laat-stadium injeksie van 'n drie-dimensionele smeltsel netwerk fasiliteer vernouing van die Holland's koepel verby die plooisluitingsstadium gedurende aanhoudende regionale verkorting. Graniet injeksiekomplekse soortgelyk aan die van die Holland's koepel is algemeen in die middel-aardkors van die Damara gordel. Die teenwoordigheid van die injeksiekomplekse beklemtoon die betekenis van die regionaalskaalse plooiing vir die vorming van tydelike magma akkumulasie gebiede en die herverdeling van progressiewe meer gefraksioneerde smeltsels gedurende vervorming van die bo-solidus aarkors. 


\section{Acknowledgements}

Alex Kisters... "Thanks" is such an unimaginative and plain word; I don't think to just say "thanks" would ever suffice. Your enthusiasm towards the work truly makes you the best teacher and mentor! I'll never ever forget the opportunity of days spent in the field learning from you, tea-time and, like many before me mentioned, the post-field day beer(s) or "coffee". Those days were most definitely the highlight of my entire university career. Thanks for every opportunity you've given and all the valuable lessons you taught.

Swakop Uranium - for financial and logistical support during field work. Berti and Guy thanks for making all the arrangements during field work, you've provided me with possibly the most interesting and beautiful study area imaginable. Deon, thank you so much for being such a trustworthy field assistant.

Ma, Pa, Frikkie, Ouma- julle gebede het my elke dag gedra. Dankie vir julle eindelose ondersteuning, motivering, raad en leiding, vir julle geduld om te luister wanneer ek afpak ek sal nooit kan opmaak vir alles wat ek gemis het die laaste paar jaar nie.

Geology family - Duncan, Stephan le Roux, Raimund, Shawn, Gautier, Andries, Leo, Andrea, Arnie, Mareli, Marelize, Kirsten, Cynthia, Capucine, Clint, Shane, (Super)Jaco, Carlo, Theo, Stephan Lubbe, Kathryn, Valby, Marcos, Francesco, Loxie. Thanks for putting up with my daily rants, the words of encouragement, advice, the best dinner parties, improving my music taste, and making Stellies memorable through this roller-coaster ride that was the last couple years. I've learnt many life lessons from you; you've genuinely enriched my life!

Above all else, I give thanks to God. The path you've led me on has been quite an interesting ride. 


\section{Table of Contents}

Page

Declaration

Abstract

iii

Opsomming

V

Acknowledgements

vii

Table of Contents

viii

List of Figures

ix

List of Abbreviations

xi

Chapter 1: Introduction

1.1. Preface and research rationale

Chapter 2: Background

2.1. General background on magma migration in the crust

2.2. Regional Geology

Chapter 3: Magma accumulation and segregation during regional-scale

folding: the Holland's dome granite injection complex, Damara belt, Namibia

Chapter 4: Synopsis and Conclusions

4.1. Synopsis and conclusions

4.2. Future work

References

Appendix A: Research Outputs 36 


\section{List of Figures}

Figure

Page

\section{Chapter 1}

Fig. 1.1 Simplified geological map illustrating the distribution of the main stratigraphic units of the Damara Supergroup in the sCZ.

Fig. 1.2 Google Earth images showing (a) the location of the Holland's dome and adjoining areas relative to the Husab Mine, and (b) the sheet-like nature of the leucogranites that intrude the Holland's dome.

\section{Chapter 2}

Fig. 2.1 Plate of figures illustrating the contrasting geometries of leucogranite networks in and around the study area.

\section{Chapter 3}

Fig. 3.1 Schematic geological map of the Damara belt in central Namibia.

Fig. 3.2 Simplified geological map of the Swakop River region and study area.

Fig. 3.3 Schematic cross-section a-d. Section line indicated on Fig. 2.

Fig. 3.4 Simplified geological map of the HD.

Fig. 3.5 (a) and (b): Field appearance of Set 1a leucogranites. (c) Stereonet indicating the orientation of Set 1a leucogranite with respect to the HD.

Fig. 3.6 (a) and (b): Field appearance of subset Set 1b leucogranites. (c) Stereonet indicating the orientation of Set $1 b$ leucogranites with respect to the HD.

Fig. 3.7 (a) Calc-silicate boudin intruded by Set 2 leucogranites (b) Stereonet indicating the orientation of Set 2 leucogranites with respect to the HD. 
Fig. 3.8 (a) Photograph and (b and c) annotated line drawings of the vertical cross-section of a cliff in the central parts of the HD hinge zone.

Fig. 3.9 (a) and (b) Google Earth images and corresponding geological maps illustrating foliation disruption in a parasitic M-fold in the hinge zone of the HD, and the high-angle intersection of Sets 1 and 2 leucogranites resulting in a T-shaped intersection, respectively.

Fig. 3.10 Field photograph of a Set 1a leucogranite sheet showing internal sheeting with varying degrees of deformation, composition and texture.

Fig. 3.11 Field photograph of a Set 1a leucogranite sheet displaying chocolatetablet pinch-and-swell and boudinage.

Fig. 3.12 Multiple intrusive relationships in Set 2 leucogranite sheets.

Fig. 3.13 Simplified form line map of the HD, highlighting the presence of lateral displacement of the calc-silicate fels marker unit along syn-magmatic shear zones. Inset (b) is a schematic 3D block diagram along section line $\mathrm{X}-\mathrm{Y}$.

Fig. 3.14 (a) and (b): Dextral sense of shear indicated by wall-rock drag and sigmoidal xenoliths of Kfm within Set 1a leucogranite.

Fig. 3.15 Google Earth image and corresponding geological map of a rhombshaped granite blow of dilational jog geometry given the dextral sense of shear along Set 1a leucogranites.

Fig. 3.16 Schematic sketches illustrating the envisaged progressive evolution of the HD injection complex.

Fig. 3.17 Schematic sketch illustrating the orientation, geometry and displacement recorded along the main leucogranite sheets and their significance for deformation of the HD. 


\section{List of Abbreviations}

\begin{tabular}{|c|c|c|c|}
\hline${ }^{\circ} \mathrm{C}$ & Degrees Celsius & $\mathrm{sCZ}$ & south Central Zone \\
\hline AMC & Abbabis Metamorphic Complex & $\mathrm{SE}$ & southeast \\
\hline $\operatorname{cs}$ & Calc-silicate fels & SMZ & Southern Margin Zone \\
\hline $\mathrm{D}_{1 / 2 / 3}$ & deformation events & SW & southwest \\
\hline $\mathrm{F}_{2 / 3}$ & folding related to $D_{2 / 3}$ & SZ & Southern Zone \\
\hline $\mathrm{Fm}$ & Formation & $\mathrm{T}$ & Temperature \\
\hline $\mathrm{Ga}$ & Billion years & UTM & Universal Transverse Mercator \\
\hline ggr & Grey granite & vol. \% & volume percentage \\
\hline Hbl-Bt-Gn & Hornblende-biotite gneiss & WGS & World Geographical System \\
\hline HD & Holland's dome & & \\
\hline kbar & Kilobar & & \\
\hline $\mathrm{Kfm}$ & Khan Formation & & \\
\hline $\mathrm{L}_{2}$ & $\begin{array}{l}\text { Stretching lineation formed } \\
\text { during } D_{2}\end{array}$ & & \\
\hline $\lg$ & leucogranite & & \\
\hline $\mathrm{m}$ & metres & & \\
\hline Мa & Million years & & \\
\hline $\mathrm{nCZ}$ & north Central Zone & & \\
\hline $\mathrm{NE}$ & northeast & & \\
\hline NW & northwest & & \\
\hline $\mathrm{NZ}$ & Northern Zone & & \\
\hline OLZ & Okahandja Lineament Zone & & \\
\hline OML & Omaruru Lineament Zone & & \\
\hline $\mathrm{P}$ & Pressure & & \\
\hline $\mathrm{S}_{0 / 1}$ & $\begin{array}{l}\text { bedding and bedding-parallel } \\
\text { foliation }\end{array}$ & & \\
\hline $\mathrm{S}_{2}$ & axial planar foliation & & \\
\hline
\end{tabular}




\section{Chapter 1: Introduction}

\subsection{Preface and research rationale}

Namibia is the world's $6^{\text {th }}$ largest uranium producer (World Uranium Mining Production World Nuclear Association, 2016). Much of this production comes from highly fractionated leucogranites in the south Central Zone (sCZ) of the Pan-African Damara belt (Fig. 1.1). For the most part, these leucogranites form sheet-like bodies and geometrically complex, commonly interconnected networks (e.g. Kinnaird and Nex, 2007; Miller, 2008; Kisters et al., 2009, 2012; Longridge et al., 2011; Hall and Kisters, 2012, 2016; Corvino and Pretorius, 2013). The leucogranites intruded into high-grade metamorphic, suprasolidus $\left(\mathrm{T} \sim 700-750^{\circ} \mathrm{C}, \mathrm{P} \sim 4-6\right.$ kbar; Jung and Mezger, 2003) crust, although in-situ partial melting of the supracrustal wallrocks of the Damara Supergroup is volumetrically minor and only locally observed in the metapelitic rock types (Ward et al., 2008). Instead, geochemical considerations indicate most of the leucogranites to have been derived through low degrees of partial melting of older granites and gneisses that form the deeper basement underlying the sCZ (McDermott et al., 1996). Hence, the leucogranite complexes in the $\mathrm{sCZ}$ are best described as granite injection complexes that illustrate the processes of magma migration and emplacement in suprasolidus crust, but largely outside the zone of partial melting.

The bulk of the uraniferous leucogranites have traditionally been interpreted to represent late-stage, post-tectonic granites emplaced after the main phase of tectonism in the Damara belt (Nex et al., 2001; Kinnaird and Nex, 2007; Miller, 2008). In contrast, more recent geochronological (Jung, 2000; Jung and Mezger, 2003; Longridge, 2012) and structural work (Kisters et al., 2009; Longridge et al., 2011; Hall and Kisters, 2012, 2016) highlight the structurally controlled emplacement of the leucogranites during regional northwest-southeast 
directed subhorizontal shortening related to the main phase of crustal convergence and collisional tectonics ( $\mathrm{D}_{2}$, after Jacob, 1974; $\mathrm{D}_{3}$ after Miller, 1983, 2008). Importantly, the wellexposed sections along the Khan and Swakop rivers illustrate systematic changes in the geometry and orientation of granite injection complexes depending on (1) their structural position with respect to regional structures (folds and thrusts) and (2) wall-rock lithologies. These variations, often over short lateral distances, have obvious ramifications for exploration and mining and require an understanding of the actual emplacement controls of the leucogranite sheets. These considerations form the background of the present study.

The Holland's dome is a regional-scale fold structure, forming part of the northeastsouthwest trending pattern of kilometre-scale, more or less upright and gently-doubly plunging folds $\left(\mathrm{F}_{2}\right)$ in the sCZ (Figs. 1.1 and 1.2). The first-order fold of the Holland's dome is developed in hornblende gneisses, hornblende-biotite schists and massive garnet-diopside granofelses, locally referred to as calc-silicate felses, of the Khan Formation, overlain by the marbledominated Rössing Formation. These formations form the base of the Damara Supergroup overlying the Paleo- to Mesoproterozoic gneissic basement of the Congo Craton (Fig. 1.1). For the most part, the Holland's dome is underlain by intrusive leucogranites. These leucogranites constitute 40 to $80 \%$ of the area. The leucogranites have led to the dismemberment of the original stratigraphy and much of the first-order fold is only discernible through isolated marker units. Previous regional exploration had identified elevated uranium values associated with leucogranites of the Holland's dome. The significance of the Holland's dome as a prime exploration target was further underlined by its along-strike position from the recently discovered, large Husab Mine that explores similar leucogranite networks, although largely under sand cover (Fig. 1.2a). This prompted this research project and the formulation of the following research aims: 
1. the structural and lithological re-appraisal of the basement-cover succession around the Holland's dome and adjoining areas and extending to the northeast to the Husab Mine;

2. the structural position and evolution of the fold within the more regional structural framework;

3. the documentation of the geometry, orientation and internal structure of the leucogranite network of the Holland's dome, intrusive wall-rock relationships, but also internal contacts within granite sheets;

4. the relationship between the structural evolution of the Holland's dome and granite sheeting, and, in general, the role of deformation, here folding, for granite emplacement.

The thesis presented here summarizes the results related to the latter two research questions, namely the spatial and temporal relationships of leucogranite sheets with respect to folding and our understanding of magma migration during regional deformation and folding. The results have been formulated in a manuscript submitted to the Journal of Structural Geology in midFebruary 2016. The manuscript was accepted for publication and appears in the August 2016 (vol. 89) edition of the Journal of Structural Geology (doi:10.1016/j.jsg.2016.05.002). New and revised aspects of the regional geology and structural evolution of the area are implicit in this model, but are not discussed in any further detail than being presented in the new and modified regional maps of the region and cross-sections. 


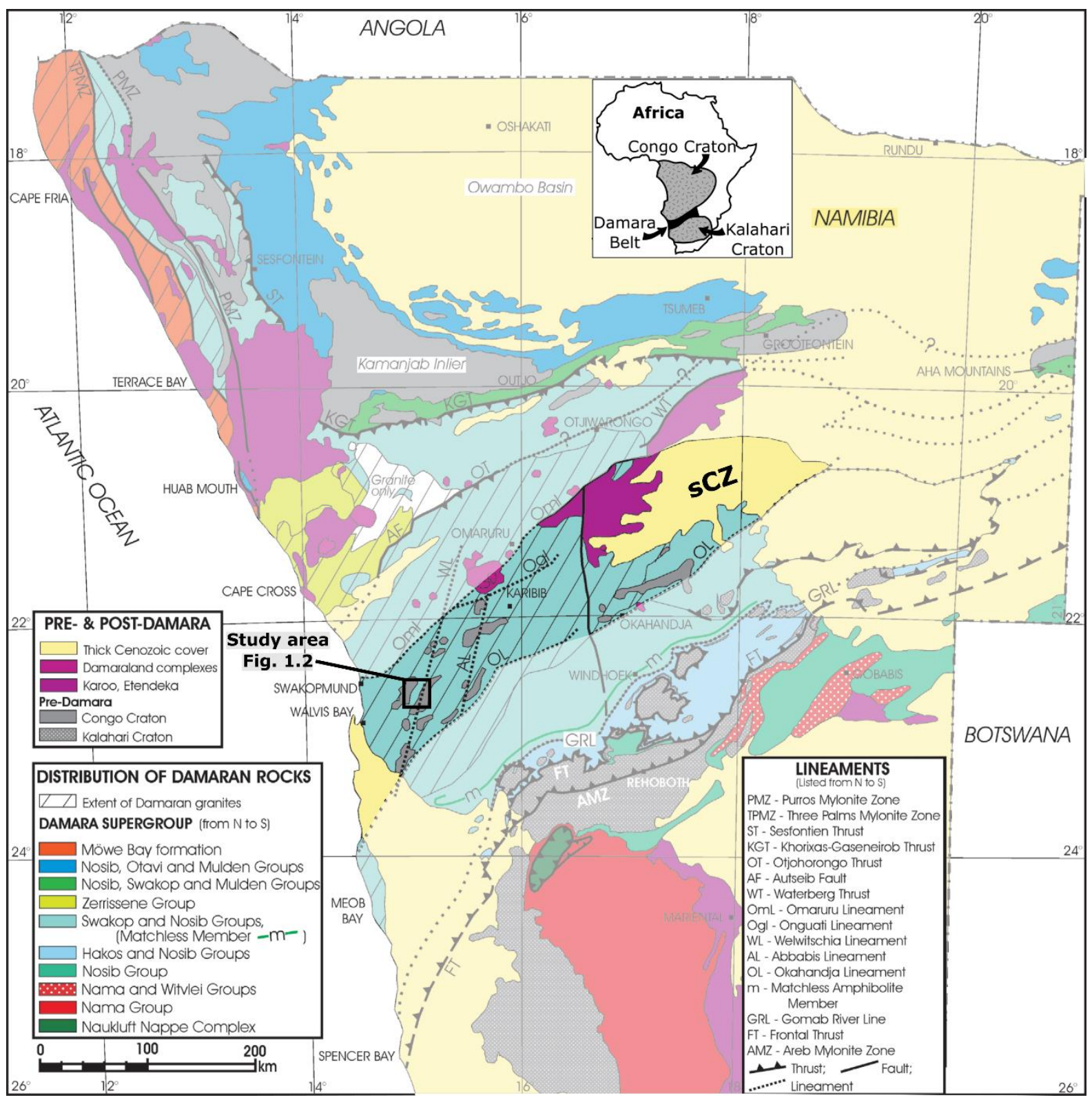

Fig. 1.1: Simplified geological map illustrating the distribution of the main stratigraphic units of the Damara Supergroup and the location of the study area within the south Central Zone (sCZ). Adapted from Miller (2008). 


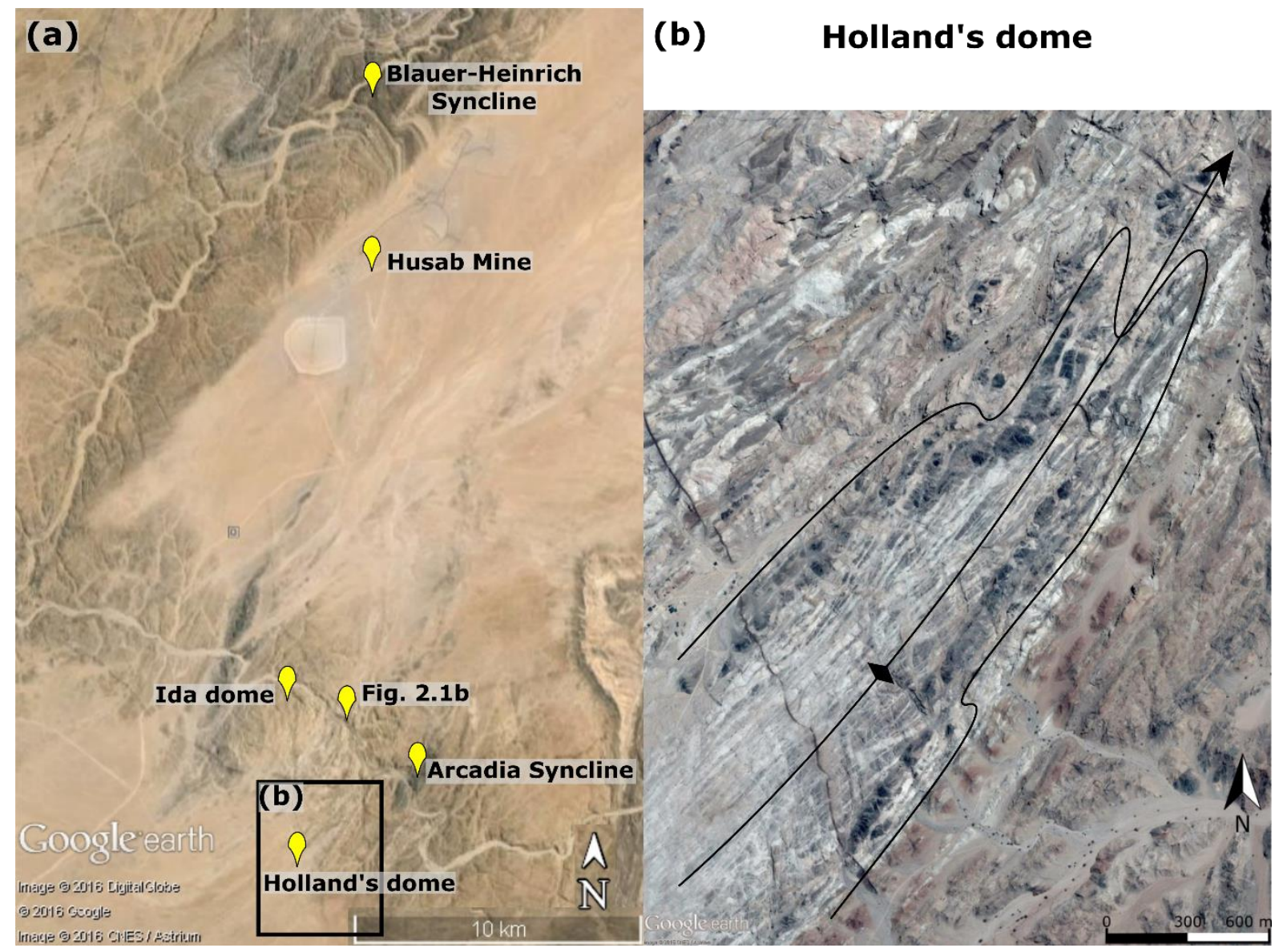

Fig. 1.2: Google Earth images showing (a) the location of the Holland's dome and adjoining areas relative to the Husab Mine, and (b) the sheet-like nature of the leucogranites (white) that intrude the Khan Formation (medium to dark grey) of the Holland's dome. 


\section{Chapter 2: Background}

\subsection{General background on magma migration in the crust}

Migmatite terranes provide insights into the internal architecture of melt segregation and transfer pathways in the mid- and lower crust, within or close to the anatectic source (Brown, 2001). In the past, several mechanisms have been proposed for the segregation and ascent of granitic magmas. There is now wider consensus that magma transfer is largely fracture controlled, either through dykes and dyke networks (e.g. Clemens and Mawer, 1992; Petford et al., 1994, 2000), self-propagating hydrofractures (e.g. Weertmann, 1971; Sleep, 1988; Bons et al., 2004; Kisters et al., 2009) or ductile fractures (e.g. Weinberg and Regenauer-Lieb, 2010; Sawyer, 2014; see comprehensive reviews by Brown, 2007, 2013 for a compilation of different processes). The relatively fast strain rates associated with most different modes of fracturecontrolled magma migration prevent the granitic magmas from freezing, particularly in subsolidus crust (e.g. Clemens and Mawer, 1992).

This fracture-controlled magma transfer is particularly well illustrated in the deeplyeroded parts ( $\mathrm{T} \sim 700-750^{\circ} \mathrm{C}, \mathrm{P} \sim 5-6 \mathrm{kbar}$; Jung and Mezger, 2003; Ward et al., 2008) of the sCZ of the Damara belt and superbly exposed in and along the dry river beds of the Khan and Swakop rivers (Fig. 1.2 and 2.1). Here, basement gneisses and cover rocks of the Damara Supergroup are pervasively intruded by typically sheet-like granites and leucogranites (Fig. 2.1). In contrast, larger plutonic complexes are rare and even more massive granite bodies can be seen to be made up of multiple sets of cross-cutting or amalgamated sheet-like batches. This not only illustrates the fracture-controlled transfer of the magmas, but also the stepwise extraction of magmas from the anatectic source and the incremental growth or assembly of larger plutons through many smaller melt batches (e.g. Glazner et al., 2004). Despite the 

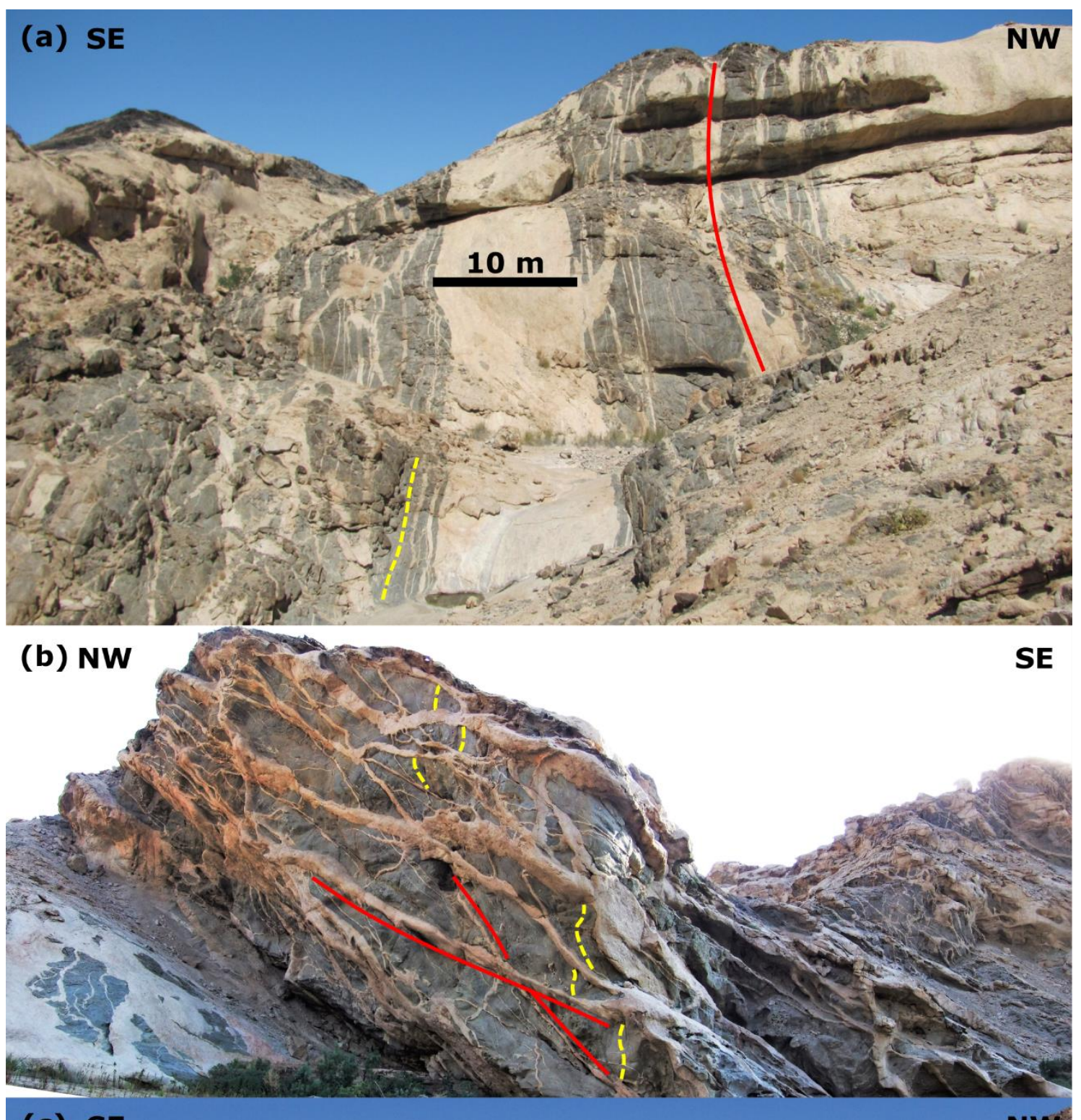

(c) SE

NW

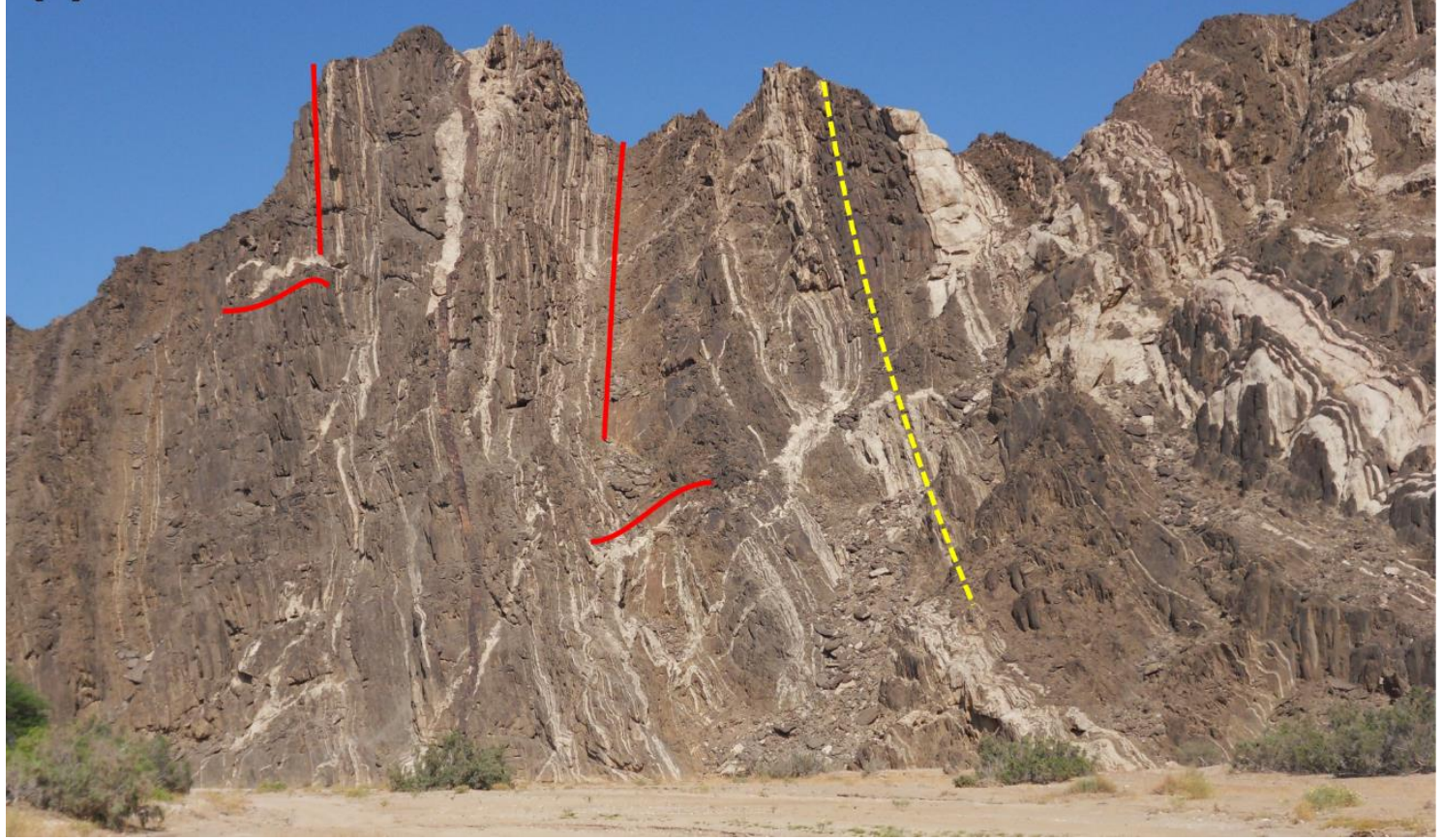


Fig. 2.1: Field photographs illustrating the sheet-like nature and fracture-controlled transport of leucogranites in different parts of the sCZ. (a) Subvertical, NE-trending Set 1 leucogranite sheets (Kruger and Kisters, 2016) intruding sub-parallel to the axial plane of the Holland's dome (Fig. 1.2b). (b) Shallow-dipping conjugate sets of leucogranite sheets in Khan Fm wall rock just east of the central parts of the Ida dome (Fig. 1.2a). Khan Fm wall rock xenoliths remain intact and show no evidence of rotation in both (a) and (b); (c) Two sets of leucogranites intruding the Kuiseb Fm metapelites in the Blauer-Heinrich Syncline (Fig. 1.2a): The main set is subvertical and bedding-parallel and the second set is shallow-dipping, at high angles to the regional stretch, and cross-cuts the bedding and main set at high angles. In all images: yellow dashed lines indicate wallrock foliation; red solid lines indicate leucogranite sheet sets. Despite the different set geometries, the sheet-like nature of these leucogranites indicate that emplacement is fracture controlled. The fact that these leucogranite sheet sets have such contrasting geometries within the same formation or just along strike of each other highlights the fact that the controls on emplacement can be very different for different localities even if they are in close proximity to each other.

volume of granites in this part of the sCZ, detailed mapping can identify distinct leucogranite sets with distinct orientations and geometries, both on a local and a regional scale. This suggests that the formation of leucogranite sets is controlled by external factors, namely regional deformation and/or local structures and lithological contrasts. The Holland's dome and associated leucogranites (Fig. 2.1a) document these combined processes of incremental granite sheeting and the relationship to regional deformation and structures particularly well.

\subsection{Regional Geology}

The Damara belt (Fig. 1.1) is a Neoproterozoic, northeast-trending orogenic belt that formed during the amalgamation of the supercontinent Gondwana (ca. 580-500 Ma). The Congo craton in the north and Kalahari craton in the southeast initially rifted apart at ca. 800-750 Ma and was accompanied by contemporaneous volcaniclastic sedimentation. Convergence of the two cratons ensued at ca. 650-600 Ma and led to the "soft" collision (Meneghini et al., 2014) and the north-westward subduction of the Kalahari- beneath the Congo craton (Miller, 1983) terminating at ca. 542-500 Ma (Miller, 2008; Gray et al., 2008). Three tectonostratigraphic subdivisions trending parallel to the orogen have been classified based on tectonic/structural 
setting, lithology, igneous activity and the dominant metamorphic facies conditions (Miller, 1983). The three zones are the Northern Zone (NZ), the Central Zone (CZ) and the Southern Zone (SZ). The NZ comprises of a low grade metamorphic, northwest-verging foreland foldand-thrust belt (Miller, 2008). The CZ represents the high-temperature, low-pressure (HTLP) $\left(\sim 750-800{ }^{\circ} \mathrm{C}, \sim 4-5 \mathrm{kbar}\right)$ metamorphic core and magmatic arc of the orogen with significant calc-alkaline magmatism (Goas Intrusive Suite) (565-500 Ma (De Kock et al., 2000)) and Stype granite plutonism (530-515 Ma). Separating the CZ from the SZ is a geophysically linear feature and collisional suture zone between the two cratons, the Okahandja lineament. The SZ represents a medium-T, medium-P (MTMP) $\left(\sim 400-640{ }^{\circ} \mathrm{C}, 6-8 \mathrm{kbar}\right)$ zone of metaturbiditic rocks structurally classified as the accretionary prism of the orogenic belt (Miller, 1983; Stanistreet et al., 1991).

The $\mathrm{CZ}$ is further divided into northern (nCZ) and southern ( $\mathrm{sCZ}$ ) divisions where the sequence exposure becomes structurally higher northwards (Miller, 2008). The deeply eroded $\mathrm{sCZ}$ is situated on the leading edge of the Congo Craton and exposes the mid- to lower crustal levels of the magmatic arc, comprising Paleoproterozoic (1.8-2 Ga) basement complex rocks that are unconformably overlain by Neoproterozoic (ca. 750-600 Ma) Damara Supergroup metasediments (Fig. 1.1). The basement complex is referred to as the Abbabis Metamorphic Complex (AMC) and mainly consists of quartzofeldspathic gneisses with intercalated supracrustal rocks (Smith, 1965; Jacob, 1974; Miller, 1983, 2008). The Damara Supergroup is characterized by coarse-clastic metasediments that grade into a mixed siliciclastic-carbonate sequence of schists and marbles (Miller, 1983, 2008; Stanistreet et al., 1991).

Lower stratigraphic units of the Damara sequence including basement rocks in the south-western parts of the sCZ have been affected by widespread granite plutonism for the period 550-500 Ma, peaking at ca. 520-500 Ma (Nex et al., 2001; Jung and Mezger, 2003; 
Longridge et al. 2011), and accompanied by upper amphibolite to lower granulite-facies metamorphic conditions ( $\mathrm{T} \sim 750{ }^{\circ} \mathrm{C}, \mathrm{P} \sim 5 \mathrm{kbar}$ ) (Jung and Mezger, 2003; Ward et al., 2008). Within this HTLP sCZ there is a notable metamorphic gradient parallel to the strike of the orogen and decreases from granulite facies in the southwest to lower-amphibolite facies in a north-easterly direction towards the Karibib district (Masberg, 2000). Metamorphism for the sCZ has been described as either long-lived or episodic between ca. 540-500 Ma and is related to the peak of the granite plutonism (Jung and Mezger, 2003). Emplacement of these granites has traditionally been interpreted as post-tectonic (Miller, 2008; Longridge, 2012), however recent geochronological (Jung, 2000; Jung and Mezger, 2003; Longridge, 2012) and structural work (Kisters et al., 2009; Longridge et al., 2011; Hall and Kisters, 2012, 2016) suggest that emplacement was structurally controlled and related to the main phase of deformation during convergence ( $D_{2}$, after Jacob, 1974; $D_{3}$ after Miller, 1983, 2008).

The structural evolution of the belt is a controversially discussed topic, but for the most part studies agree that there is an early bedding-parallel or low-angle fabric assigned to a $\mathrm{D}_{1}$ deformation phase, including regional-scale low-angle thrusts and recumbent folds (Jacob, 1974; Miller, 1983; Kisters et al., 2004; Longridge, 2012). $\mathrm{D}_{1}$ structures have been affected by $\mathrm{D}_{2}$ (after Jacob, 1974), characterized by refolding of $\mathrm{D}_{1}$ structures by upright, northeasttrending $\mathrm{F}_{2} / \mathrm{D}_{2}$ folds. Northeast-trending $\mathrm{D}_{2}$ fabrics and structures dominate the structural grain of the belt. A pervasive northeast-trending, steeply-dipping to subvertical $\mathrm{S}_{2}$ foliation is axial planar to $F_{2}$ folds and shallow- to moderately northeast-plunging, orogen-parallel mineral stretching/rodding $\mathrm{L}_{2}$ lineations are parallel to $\mathrm{F}_{2}$ fold hinges. The $\mathrm{L}_{2}$ lineations are prominent in the $\mathrm{sCZ}$ and are interpreted to indicate lateral extrusion of the mid-crust in response to the high-angle subhorizontal shortening during northwest-southeast convergence $\left(D_{2}\right.$, Oliver, 1994; Poli and Oliver, 2001; Kisters et al., 2004, 2012). 


\section{Chapter 3: Magma accumulation and segregation}

This chapter constitutes a presentation of a published research $\operatorname{paper}^{1}$ : Magma accumulation and segregation during regional-scale folding: the Holland's dome granite injection complex, Damara belt, Namibia by Kruger and Kisters.

${ }^{1}$ Kruger, T. \& Kisters, A., 2016. Magma accumulation and segregation during regional-scale folding: the Holland's dome granite injection complex, Damara belt, Namibia. Journal of Structural Geology 89, 1-18, http://dx.doi.org/10.1016/j.jsg.2016.05.002 


\title{
Magma accumulation and segregation during regional-scale folding: The Holland's dome granite injection complex, Damara belt, Namibia
}

\author{
Tolene Kruger*, Alexander Kisters \\ Department of Earth Sciences, University of Stellenbosch, Private Bag X1, Matieland 7602, South Africa
}

\section{A R T I C L E I N F O}

\section{Article history:}

Received 16 February 2016

Received in revised form

3 May 2016

Accepted 13 May 2016

Available online 13 May 2016

\section{Keywords:}

Magma migration

Injection complex

Permeability network

Leucogranite

Deformation-driven fractionation

Damara belt

\begin{abstract}
A B S T R A C T
The regional-scale, upright fold of the Holland's dome in the Damara belt of central Namibia contains a kilometre-scale network of intrusive, highly fractionated uraniferous leucogranites. Three broadly orthogonal and intersecting sets of leucogranite sheets that intruded parallel and at right angles to the axial plane of the first-order fold can be distinguished. The granites are internally sheeted and illustrate the growth of the injection complex through the successive addition of thousands of smaller magma batches. Spatial and timing relationships point to a stepwise evolution of the injection complex. Early dilatancy-driven segregation and accumulation of granitic magmas in the core of the fold, above a basal detachment, was followed by compaction-driven segregation of a melt phase during fold tightening. The intersecting leucogranite sets provide a suitably organized permeability structure for melt segregation, while the successive injection of magma batches ensures compatibility between regional strain rates during folding and the rates of magma segregation. The three-dimensional network of melt-bearing structures further assisted regional shortening past the lock-up of the fold. The Holland's dome injection complex illustrates the geometric complexity of magma transfer pathways and the significance of regional-scale folding for the accumulation, segregation and fractionation of granitic magmas in suprasolidus crust.
\end{abstract}

(1) 2016 Elsevier Ltd. All rights reserved.

\section{Introduction}

Our understanding of the ascent of felsic magmas through the crust largely relies on observations and interpretations of granitic dyke networks from mid-crustal anatectic terrains (e.g. Wickham, 1987; Brown, 1994, 2007, 2010; Sawyer, 1994; Collins and Sawyer, 1996; Weinberg, 1996; Bons and van Milligen, 2001; Bons et al., 2004, 2010; Brown et al., 2011). These networks are interpreted to represent the vestiges of original melt migration pathways recording the initial segregation of melts from their partially molten protoliths into veins and stringers to the transfer and accumulation of magmas to form larger sheets or interconnected vein complexes (Jurewicz and Watson, 1984; Vigneresse, 1995; Weinberg, 1999; Weinberg and Searle, 1998; Brown, 2007; Sawyer, 2008, 2014; Hall and Kisters, 2012; Diener et al., 2014; Soesoo and Bons, 2014). Deformation plays an integral role in the mobilization of melts and magmas which,

\footnotetext{
* Corresponding author.

E-mail addresses: tolenem.kruger@gmail.com (T. Kruger), akisters@sun.ac.za (A. Kisters).
}

in turn, leads to strain localization and the partitioning of deformation (van der Molen and Paterson, 1979; Hollister and Crawford, 1986; Rushmer, 1995; Brown and Solar, 1998; Rosenberg and Handy, 2001, 2005). It is therefore not surprising that many studies describe processes of magma migration from crustal-scale transcurrent or transpressive shear zones. In shear zones, shear zone foliations, but also shear zone kinematics provide subvertical permeability pathways that facilitate the vertical and mainly buoyancy-driven ascent of the granitic magmas (e.g., Brown and Solar, 1998). However, the high finite strains invariably associated with shear zones also tend to overprint and transpose initial sheet geometries so that the original permeability networks may not be preserved (Weinberg et al., 2009; Reichardt and Weinberg, 2012; Morfin et al., 2013).

Folds are ubiquitous features of any anatectic terrain and numerous studies have documented a close spatial and temporal relationship between folds and granitic magmas or plutons (e.g., Allibone and Norris, 1992; Hand and Dirks, 1992; Vanderhaeghe, 1999; Barraud et al., 2001, 2004; Vernon and Paterson, 2001; Weinberg et al., 2015). Granite networks in folds may not have contributed to a crustal-scale transfer of melts, given their 
commonly limited amplitude, but lower strains in folds may better preserve the permeability structures that accommodated magma transfer over distances of several hundred meters up to a few kilometres. As such, these networks probably represent an important stage in the stepwise redistribution and accumulation of magmas in suprasolidus crust that most studies assume to be essential for the initiation of far-field granite ascent through the subsolidus crust (Bons et al., 2010; Diener et al., 2014; Hall and Kisters, 2016).

Leucogranites in the deeply eroded south Central Zone (sCZ) of the Damara Belt in Namibia (Fig. 1) document the processes of magma segregation and transfer close to, but outside the anatectic zone and in suprasolidus crust $\left(\mathrm{T} \sim 700-750{ }^{\circ} \mathrm{C}, \mathrm{P} \sim 5 \mathrm{kbar}\right)$ (Jung and Mezger, 2003; Ward et al., 2008). The highly fractionated, uraniferous leucogranites are derived by partial melting of deeper-crustal basement gneisses and typically form kilometre-scale injection complexes made up of two or more sets of intersecting leucogranite sheets (Hall and Kisters, 2012). Most of these granite networks are spatially associated with regionalscale folds, particularly antiformal structures, with a clear geometric relationship between the orientation of the granite sheet sets and the orientation of the folds. This paper documents the geometry, relative timing and controls of a kilometre-scale leucogranite injection complex and its relation to the regional-scale fold of the Holland's dome in the south-western parts of the sCZ. The results highlight the complex geometries of magma transfer pathways and the role of deformation-driven magma compaction and melt segregation during folding and fold amplification for the formation of the highly fractionated magmas.

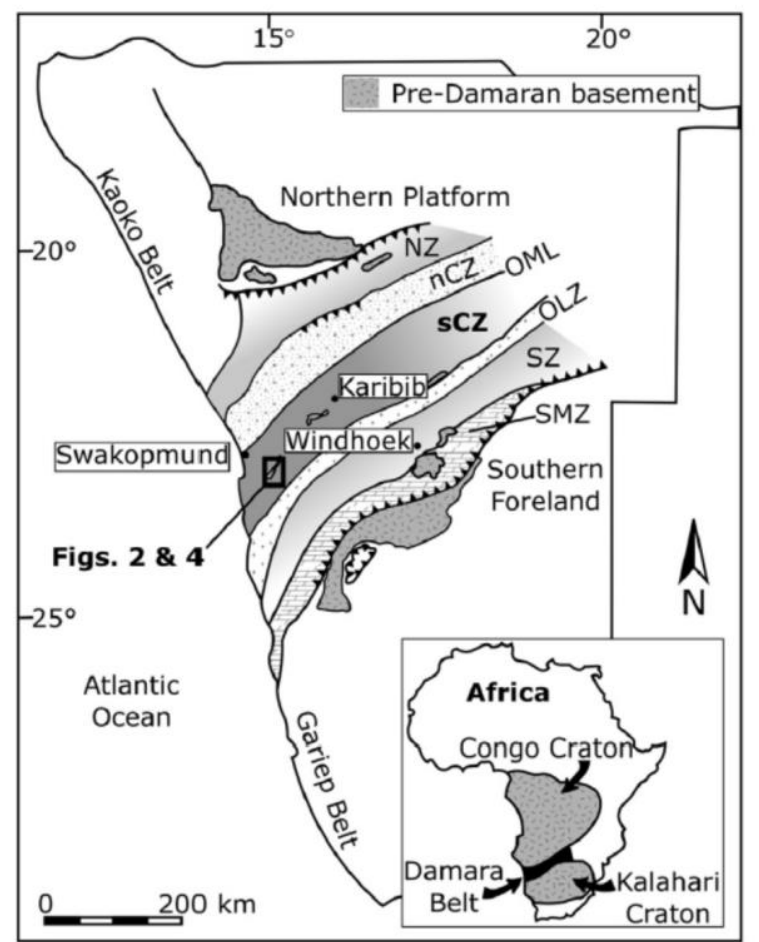

Fig. 1. Schematic geological map of the Damara belt in central Namibia showing the tectonostratigraphic zones of the belt and the location of the study area (after Miller 2008) (Figs. 2 and 4). Inset illustrates the location of the Damara belt between the bounding Congo and Kalahari cratons. $\mathrm{NZ}=$ Northern Zone; $\mathrm{nCZ}=$ north Central Zone; $\mathrm{OML}=$ Omaruru Lineament Zone; $\mathrm{SCZ}=$ south Central Zone; $\mathrm{OLZ}=$ Okahandja Lineament Zone; $\mathrm{SZ}=$ Southern Zone; $\mathrm{SMZ}=$ Southern Margin Zone.

\section{Geological setting}

Granite plutonism in the Central Zone magmatic arc of the PanAfrican Damara belt in central Namibia (Fig. 1) is related to the high-angle, north-westward subduction of the Kalahari below the Congo Craton between ca. 580 and $525 \mathrm{Ma}$ followed by the soft collision of the two cratons at ca. 525-500 Ma (Meneghini et al., 2014). The SCZ is situated on the leading edge of the overriding Congo Craton. It exposes the mid- and lower crustal levels of the magmatic arc made up of a gneissic basement, the unconformably overlying, polyphase deformed cover sequence of the Damara Supergroup and Pan-African granitic rocks intrusive into the former two. The basement rocks, collectively referred to as the Abbabis Metamorphic Complex (AMC) (Miller, 1983; Brandt, 1987), comprise mainly Paleoproterozoic $(2-1.8 \mathrm{Ga}$ ) and largely undifferentiated quartzofeldspathic gneisses with minor intercalated supracrustal rocks (Fig. 1) (Smith, 1965; Jacob, 1974; Miller, 1983, 2008; Brandt, 1987; Kisters et al., 2004; Longridge et al., 2011). The Neoproterozoic (ca. 750-600 Ma) Damara Supergroup consists of a basal, continental rift-type sequence of mainly coarse-clastic metasedimentary and, locally, metavolcanic rocks grading into a mixed siliciclastic-carbonate succession of schists and marbles (Miller, 1983, 2008; Stanistreet et al., 1991; Hoffman et al., 1996).

Granite plutonism in the $\mathrm{sCZ}$ is recorded between ca. 580-470 Ma, from the early stages of convergence to the postcollisional thermal equilibration of the belt (Miller, 1983, 2008; Jung, 2000). Most plutons have sheet- or laccolith-like geometries in the lower-grade mid- to upper crustal levels of the sCZ (Miller, 2008; Hall and Kisters, 2016). At deeper crustal levels, granites form regionally extensive net-veined or injection complexes made up of a multitude of interconnected and/or cross-cutting granite sheets (Kisters et al., 2009; Hall and Kisters, 2012). Granite plutonism is accompanied by high-T, low-P metamorphism that reached upper-amphibolite to lower-granulite conditions ( $T$ $\left.\sim 700-750^{\circ} \mathrm{C}, \mathrm{P} \sim 5-6 \mathrm{kbar}\right)$, with local partial melting of particularly metapelitic rocks in the south-western parts of the sCZ. Existing geochronological data suggest an either episodic or longlived high-T metamorphic event between ca. 540-500 Ma (Jung, 2000; Jung and Mezger, 2003; Longridge, 2012) broadly coinciding with the peak of the granite plutonism.

The details of the structural evolution of the belt are controversially discussed, but most studies agree on the presence of early bedding-parallel or low-angle fabrics and structures that are assigned to a $D_{1}$ phase of deformation. $D_{1}$ structures include outcrop-to regional-scale recumbent folds and associated lowangle thrusts (Jacob, 1974; Miller, 1983; Kisters et al., 2004; Longridge, 2012). Earlier $D_{1}$ structures and fabrics have been refolded by later, more or less upright, northeast-trending folds $\left(D_{2} / F_{2}\right)$ and associated thrusts that dominate the structural grain of the northeast-trending Damara belt. $F_{2}$ folding and thrusting are associated with regionally relatively consistent and, in places, pervasive northeast-trending fabrics $\left(\mathrm{S}_{2} / \mathrm{L}_{2}\right)$. The steep, northeasttrending $S_{2}$ foliation is axial planar to $F_{2}$ folds, while the $L_{2}$ lineation shows north-easterly trends and mostly shallow plunges, parallel to the hinges of $F_{2}$ folds. Constrictional fabrics $\left(L_{2}\right)$ are widespread in the higher-grade south-western parts of the $\mathrm{sCZ}$ and are commonly interpreted to indicate the lateral extrusion of the higher-grade mid-crustal levels during high-angle northwestsoutheast convergence $\left(D_{2}\right.$, Oliver, 1994; Poli and Oliver, 2001; Kisters et al., 2004, 2012). Irrespective of the different interpretations about the detailed structural evolution of the belt, structural and geochronological studies suggest that $D_{1} / D_{2}$ strains formed during a prolonged period (550-515 Ma) of northwestdirected, subhorizontal, largely coaxial shortening (Oliver, 1994; Goscombe et al., 2003; Kisters et al., 2004, 2012), probably 
related to the high-angle convergence and shallow subduction of the Kalahari below the Congo Craton.

\section{Geology of the Holland's dome}

\subsection{Lithostratigraphy}

The Holland's dome (HD) is a km-scale northeast-trending fold ( $F_{3}$ after Miller, 1983; $F_{2}$ after Jacob, 1974; Kisters et al., 2004) centered at $22^{\circ} 46^{\prime} 11.99^{\prime \prime} \mathrm{S}$ and $15^{\circ} 1^{\prime} 5.47^{\prime \prime} \mathrm{E}$ (Figs. 2-4). The lithostratigraphy of this part of the SCZ is dominated by the lower parts of the Damara Supergroup and the underlying basement of the AMC. The gneissic basement is exposed in the northeasttrending first-order structure of the gently doubly-plunging Ida dome, northwest of the HD (Fig. 2). Quartzite and meta-arkoses of the basal Etusis Formation of the unconformably overlying Damara Supergroup are only sporadically developed (Figs. 2 and 3). Instead, the overlying Khan Formation is more widely distributed. Khan Formation rocks include a 300-800 m thick sequence of hornblende-biotite gneisses, amphibolites and massive garnet-diopside granofelses, locally referred to as calcsilicate felses. The Khan Formation forms the core of the HD and is overlain by the lithologically heterogeneous, marbledominated Rössing Formation (Figs. 3 and 4). In the Rössing Formation, marble units tend to localize the strain and intrafolial folding and bedding transposition are common, testifying to the ductility of the marble dominated sequence. The stratigraphically higher remainder of the Damara Supergroup above the Rössing Formation is not developed around the HD.

Both the abundance and intrusive styles of Pan-African granites vary systematically across the basement-cover contact. In basement rocks, granites form irregularly shaped lenses and, in places, sheeted complexes made up of parallel-sided granite sheets. Leucogranites are abundant, but volumetrically subordinate. The actual basement-cover contact, in contrast, is developed as an up to several hundred meter wide intrusive breccia within which cross-cutting leucogranite sheets contain dismembered fragments of the basal parts of the Damara Supergroup. Above this contact, the Khan Formation is intruded by voluminous, mostly sheet-like granites that may constitute up to $80 \%$ of individual outcrops (Fig. 2) (e.g., Jacob, 1974). In the HD and adjoining areas the uraniferous (Nex et al., 2001; Corvino and Pretorius, 2013) leucogranites are mineralogically relatively homogeneous, comprising quartz, alkali-feldspar and plagioclase as their main constituents. Biotite, tourmaline and garnet occur in variable amounts and zircon, monazite, apatite, allanite and magnetite are present as accessory phases. Isotopic evidence shows that the leucogranites are crustally-derived magmas that originated from low degrees of partial melting of older, Paleoproterozoic rocks such as the basement gneisses of the AMC (Hawkesworth et al., 1983; McDermott et al., 1996; Nex et al., 2001). Leucogranites from the nearby Goanikontes location are high in $\mathrm{SiO}_{2}(68-76 \%)$ and $\mathrm{K}_{2} \mathrm{O}(4.9-11 \%)$ and low in combined $\mathrm{CaO}$ and $\mathrm{Na}_{2} \mathrm{O}$ (2.6-5.3\%) (Nex et al., 2001). Respective mineral proportions and, particularly, grain sizes are highly variable. Most leucogranites are dominated by coarse-grained, densely packed and marginally recrystallized white-to pinkish K-feldspar, minor plagioclase and mostly interstitial quartz. Grain sizes vary from medium-to very coarse-grained and pegmatitic. Variations in the modal mineral abundance and grain size, in particular, allows for the distinction of different intrusive phases in outcrop. Existing $\mathrm{U}-\mathrm{Pb}$ zircon and monazite ages from leucogranites in the vicinity yield ages of between 520 and $510 \mathrm{Ma}$ (Briqueu et al., 1980; Longridge, 2012) and indicate emplacement during the waning stages of $D_{2}$ shortening.

\subsection{Structural geology}

The HD is an upright, northeast-trending, non-cylindrical, doubly-plunging fold that forms part of the regional-scale pattern of $F_{2}$ folds in the sCZ (Fig. 4). $F_{2}$ folding has refolded the wellpreserved bedding $\left(S_{0}\right)$ and bedding-parallel gneissosity $\left(S_{1}\right)$ of Khan Formation rocks. The fold is associated with a more or less upright axial planar foliation $\left(\mathrm{S}_{2}\right)$ and a northeast-trending stretching lineation $\left(\mathrm{L}_{2}\right)$. In the northwest, the HD shares a limb with the adjoining Garnet Valley syncline that is cored by marbles and biotite-cordierite schists of the overlying Rössing Formation (Figs. 2-4). The south-eastern limb of the HD is truncated by the Arcadia thrust, along which gneisses and amphibolites of the Palaeoproterozoic AMC are thrusted on top of the Khan Formation of the HD (Figs. 2-4). The position of the HD within the broader geology is shown in Fig. 3. The cross-section illustrates the close relationship between $F_{2}$ folds and $D_{2}$ thrusts and the disharmonic geometry of $\mathrm{F}_{2}$ folds, particularly in the Khan Formation against the underlying basement. The detachment-like folds are the result of the strain incompatibilities that arise from the only moderate dips of the basement-cover contacts, exposed around the Ida dome, and the mainly upright orientation of tight-to isoclinal $F_{2}$ folds in the competent gneisses of the overlying Khan Formation.

Leucogranites intrusive into the Khan Formation constitute some $40-80 \%$ of the core of the HD. As a result, the central parts of the HD resemble an intrusive megabreccia made up of large $(10-100 \mathrm{~m})$, angular and lozenge-shaped wall-rock fragments separated by leucogranite (Fig. 4). An up to $300 \mathrm{~m}$ wide zone of almost massive granite wraps around the core of the HD. This granite is parallel to the contact between the Khan Formation and marble units of the overlying Rössing Formation (Fig. 4). Despite the wall-rock brecciation, the first-order fold structure in the core of the HD is still discernible and delineated by a prominent, up to $60 \mathrm{~m}$ wide garnet-diopside calc-silicate fels marker unit in the upper parts of the Khan Formation. The inner parts of the HD are dominated by well-bedded and foliated $\left(S_{1}\right.$ and $\left.S_{2}\right)$ hornblendebiotite gneisses. The first-order HD thus defined can be followed for $>3.5 \mathrm{~km}$ along its gently curved axial trace and has a maximum width of some $1.1 \mathrm{~km}$ in its central parts (Fig. 4). It is a doublyplunging fold, showing gentle $\left(10-35^{\circ}\right)$ north-easterly plunges in the northeast and shallow $\left(5-10^{\circ}\right)$ south-westerly plunges of the less well exposed south-western hinge zone (Fig. 4a). Fold limbs are steep to vertical and, locally, overturned, defining the tight-to isoclinal interlimb angles of the HD (Fig. 4a). The calc-silicate marker unit is boudinaged on the north-western and south-eastern limbs of the HD (Fig. 4), consistent with the regional northeast-southwest $\mathrm{D}_{2}$ stretch in this part of the sCZ. Second- and higher-order folds show subhorizontal or shallow north-easterly plunges, parallel to the first-order $\mathrm{HD}$ and $\mathrm{F}_{2}$ folds in the region (Fig. $4 \mathrm{~b}$ ). $\mathrm{S}_{2}$ is a spaced to penetrative foliation in gneisses defined by the grain-shape preferred orientation of biotite and/or hornblende and/or flattened quartz-feldspar aggregates (Fig. 4c). The hinge-parallel, shallow northeast- and/or southwest-plunging mineral stretching lineation $\left(\mathrm{L}_{2}\right)$ is parallel to regional stretching lineations in this part of the sCZ (Fig. 4a) (Oliver, 1994; Kisters et al., 2009).

\subsection{Granites and leucogranites in the $H D$}

Angular wall-rock fragments and the breccia-like textures in the core of $\mathrm{HD}$ result from the intersection of three main and distinct sets of near-orthogonal leucogranite sheets. Leucogranites account for $>95$ vol\% of granitic material in the HD. The remainder is made up of an earlier grey granite phase that is intrusive into the Khan Formation. This granite only occurs as xenoliths in later leucogranites. An even earlier phase occurs as thin, tightly folded 


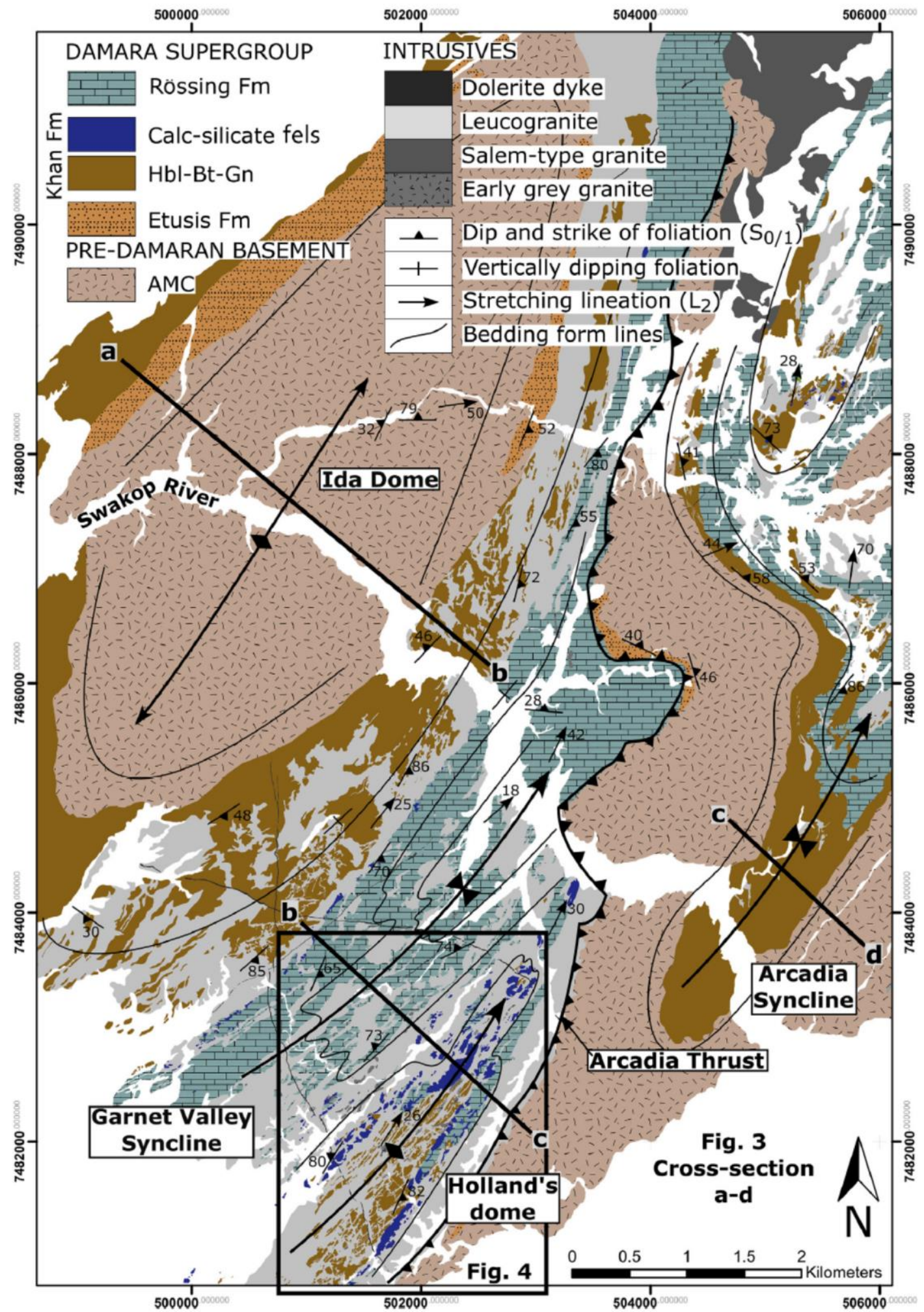

Fig. 2. Simplified geological map of the Swakop River region around the Ida dome, showing second-order folds, including the Holland's dome, and the main thrust sheet of the Arcadia thrust. Pan-African granitoids are intrusive into both the basement and the overlying Damara sequence and are particularly voluminous along the basement-cover contact (Datum: WGS 84 UTM Zone 33ㅇ) (after Smith, 1965; Jacob, 1974). Cross-section a-d shown in Fig. 3. 


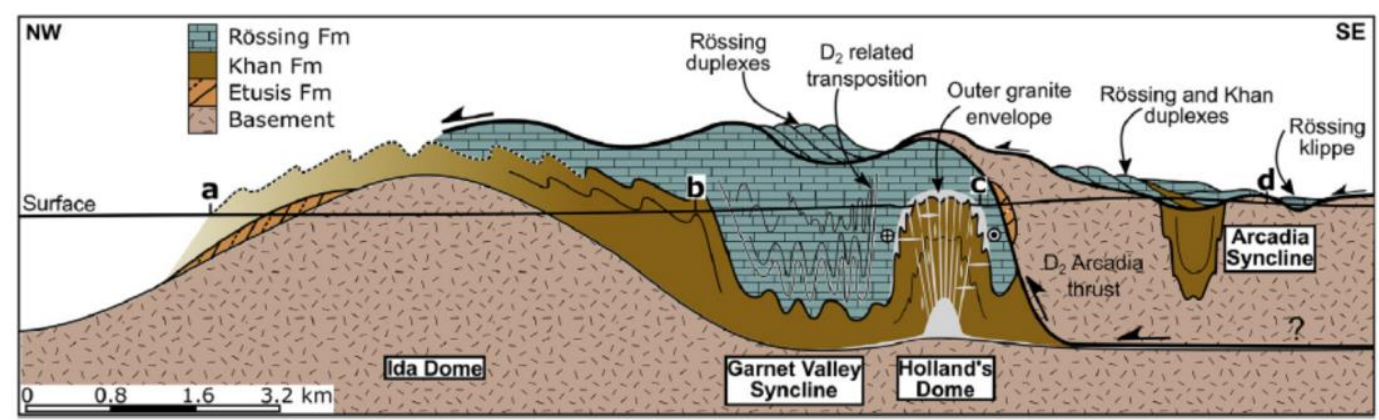

Fig. 3. Schematic cross-section (a-d) between the Ida dome and the Arcadia Syncline (Fig. 2). The section illustrates the close relationship between $F_{2}$ folds and $D_{2}$ thrusts and the disharmonic geometry of $\mathrm{F}_{2}$ folds, particularly in the Khan Formation against the underlying basement. Section line a-d shown in Fig. 2 .

bedding-parallel granite stringers in the Khan Formation.

Northeast-trending, subvertical granite sheets are roughly parallel to the axial plane of the HD and form the most prominent leucogranites, henceforth referred to as Set 1a leucogranites (Fig. 5). Set 1a leucogranites contain a subset (Set $1 b$ ) in which granite sheets show similar north-easterly trends, but with shallower dips to the northwest and southeast, describing an overall conjugate set (Fig. 6). Set 2 leucogranites comprise northwest-trending, subvertical granite sheets that cross-cut the $\mathrm{HD}$ fold axial plane and Set 1a leucogranites at nearly right angles (Fig. 7). Set 3 leucogranites include a rather subordinate set of subhorizontal granite sheets (Fig. 8). The actual abundance of Set 3 granites compared to Sets 1 and 2 leucogranites is difficult to ascertain given the limited vertical extent of exposure in the HD.

\subsubsection{Set 1 leucogranites}

The northeast-trending, subvertical Set 1a leucogranites are volumetrically the most abundant and largest granite sheets in the HD. Set $1 \mathrm{a}$ leucogranites form parallel-sided, gently undulating and spaced sheets, roughly axial planar to the HD (Figs. 4 and 5). The largest of these leucogranites are up to $25 \mathrm{~m}$ wide (Fig. 9) and can be followed for more than $1 \mathrm{~km}$ along strike. Set 1a leucogranites may intrude parallel to bedding planes, particularly on the limbs of the HD, but granite emplacement is not controlled by bedding anisotropies and leucogranite sheets cross-cut both bedding and $D_{2}$ related fabrics (Fig. 9).

Larger granite sheets are almost invariably made up of thinner (20-50 cm wide), subparallel sheets. In several places, the granite sheets show clear and commonly low-angle internal intrusive contacts that point to the assembly of wider sheets through the amalgamation of smaller and successively emplaced granite sheets (Fig.10). Individual sheets are distinguished by different grain sizes, textures and fabric development (Fig. 10). Fabric development even in adjacent sheets varies significantly and gneissic granites with pervasive solid-state fabrics may occur next to weakly or undeformed granite sheets. Gneissic fabrics are defined by the marginal or pervasive recrystallization of feldspar, the formation of quartz discs and ribbons and the preferred orientation of biotite. The subvertical solid-state foliation trends northeast and parallel to the margins of Set 1a leucogranite sheets and the regional $\mathrm{S}_{2}$ foliation in wall rocks. Less deformed or undeformed leucogranites retain their original magmatic textures or contain an only weaklydeveloped solid-state biotite fabric or flattened quartz discs. The chocolate-tablet boudinage of granite sheets indicate that Set 1a granite sheets have experienced a large component of layer-normal shortening after their emplacement (Fig. 11). These fabric relationships underscore the successive emplacement of leucogranites during $\mathrm{F}_{2}$ folding of the $\mathrm{HD}$ and at high angles to the regional northwest-southeast directed, subhorizontal shortening

Thinner, but isolated and spaced granite sheets or stringers are developed throughout the Khan Formation gneisses, but they are not nearly as voluminous as the amount of granite contained in the wider sheeted granites (Fig. 5a-b). The multiple sheeting underlines the tendency of later granite batches to follow earlier granite sheets, rather than propagating through intact wall rocks (Fig. 10). In places, individual granite sheets are separated by narrow wall-rock screens that occur as isolated xenoliths within the larger composite sheets.

Set 1 a leucogranites contain a subset of north-easterly trending sheets with shallower north-westerly and south-easterly dips (Set 1b) (Fig. 6). Set 1b granites define an overall conjugate set, with a north-easterly trending, gently plunging intersection, parallel to the hinge of the HD. The obtuse angle enclosed between the two oppositely dipping sets is typically $120-135^{\circ}$ and faces northwest and southeast. Cross-cutting relationships between granite sheets in the conjugate sets are inconsistent and suggest the multiple and successive emplacement of granites rather than the concurrent intrusion of conjugate sets (Fig. 6a-b).

\subsubsection{Set 2 leucogranites}

Northwest-trending, subvertical Set 2 leucogranites are unevenly distributed and most abundant in competent calc-silicate felses on the limbs of the HD, where the closely spaced sheets cut bedding at high angles (Figs, 4, 7 and 12). Here, Set 2 leucogranites are parallel to northwest-trending, granite-filled interboudin spaces that separate the massive garnet-diopside felses (Fig. 7). Larger and laterally more extensive sheets may also cross-cut the hornblende-biotite gneisses, but sheets terminate abruptly against interlayered marble-schist units on the south-eastern limb (Fig. 4). This also highlights the role of competence contrasts for the propagation of granite sheets in the Damara Supergroup. Granite sheeting is common in competent gneisses and calc-silicate felses of the Khan Formation. The highly ductile marble units, in contrast, inhibit fracture propagation and granite sheets abruptly terminate along these lithological contacts due to the blunting of magmafilled fractures (Kisters et al., 2009; Hall and Kisters, 2016). The high-angle intersection between the laterally extensive Set 1a and shorter Set 2 granite sheets results in the typically rectangular shape of Khan Formation wall-rock fragments in the HD (Figs. 4 and 9). Larger granite blows are located at the high-angle intersection between Set $1 \mathrm{a}$ and 2 granites (see below, Fig. $9 \mathrm{~b}$ ), but again this is not developed throughout the HD (Fig. 4).

Internal sheeting within Set 2 leucogranites is not as prominent as in the larger Set 1a granites. Where multiple internal sheets are present, earlier sheets are folded and cross-cut by later, only gently folded or undeformed sheets (Fig. 12). The folded Set 2 


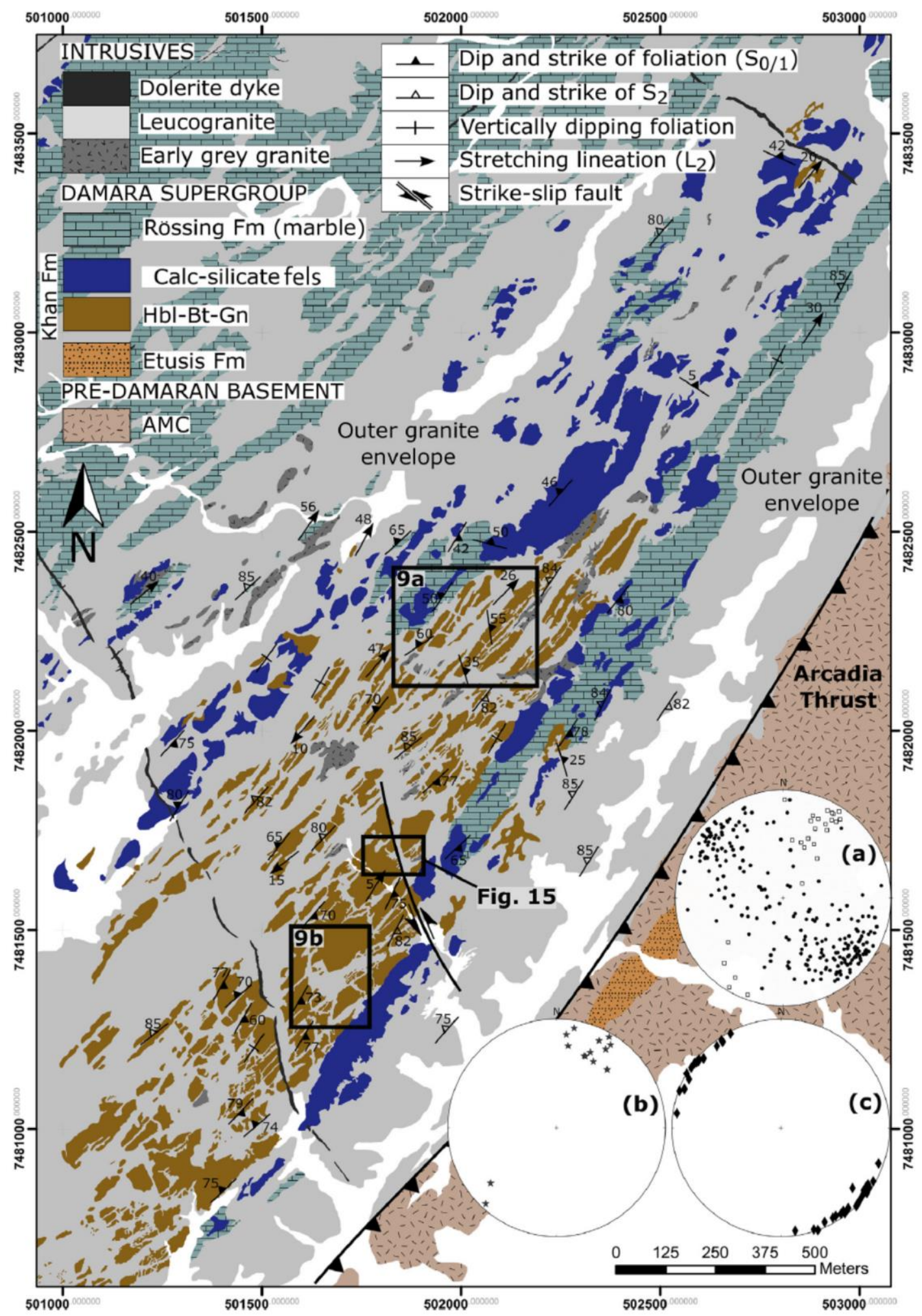

Fig. 4. Simplified geological map of the HD outlined by the massive calc-silicate layer in the upper parts of the Khan Formation and cored by hornblende-biotite gneisses, extensively intruded by sheet-like leucogranites (Datum: WGS 84 UTM Zone $33^{\circ} \mathrm{S}$ ) (after Smith, 1965; Jacob, 1974). Squares indicate the location of Fig 9a, b and 15, Lower hemisphere, equal area projections: (a) poles to bedding $\left(\mathrm{S}_{0 / 1}\right)$ (dots; $n=249$ ) in the Holland's dome first-order $F_{2}$ fold. $L_{2}$ mineral stretching/rodding lineations (hollow squares; $n=28$ ) trend NE and are gently doubly-plunging, parallel to the plunge of the first-order $F_{2}$ fold; $(\mathbf{b}) F_{2}$ fold plunges in the $H D(s t a r s ; n=15) ;(c)$ poles to axial planar foliation ( $\left.S_{2}\right)$ (diamonds, $\mathrm{n}=56$ ) in the HD. 


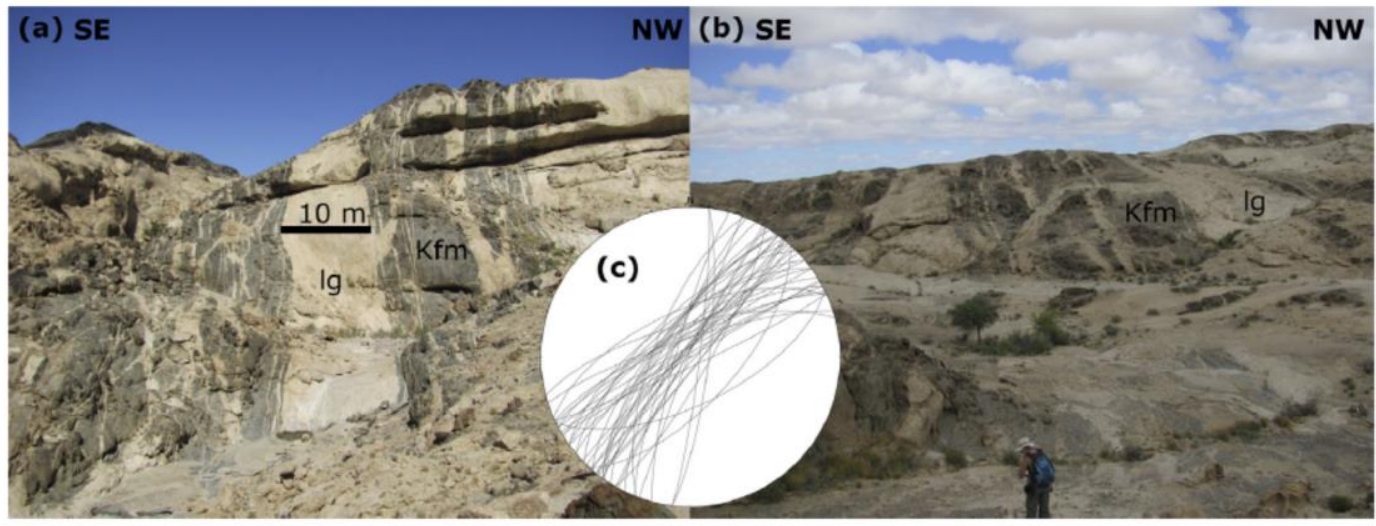

Fig. 5. Field appearance of Set 1a leucogranites. (a) Cross-sectional view (to the SW) of subvertical main Set 1a leucogranites in gneisses of the Khan Formation; (b) oblique view (to the SW) of mainly Set 1a leucogranites; (c) lower hemisphere, equal area projection of Set 1a leucogranites $(\mathrm{n}=45)$ indicating the broadly axial planar orientation of Set 1 a leucogranites with respect to the $\mathrm{HD}$. $\mathrm{Kfm}=$ Khan Formation (xenoliths); $\mathrm{lg}=$ leucogranite sheet

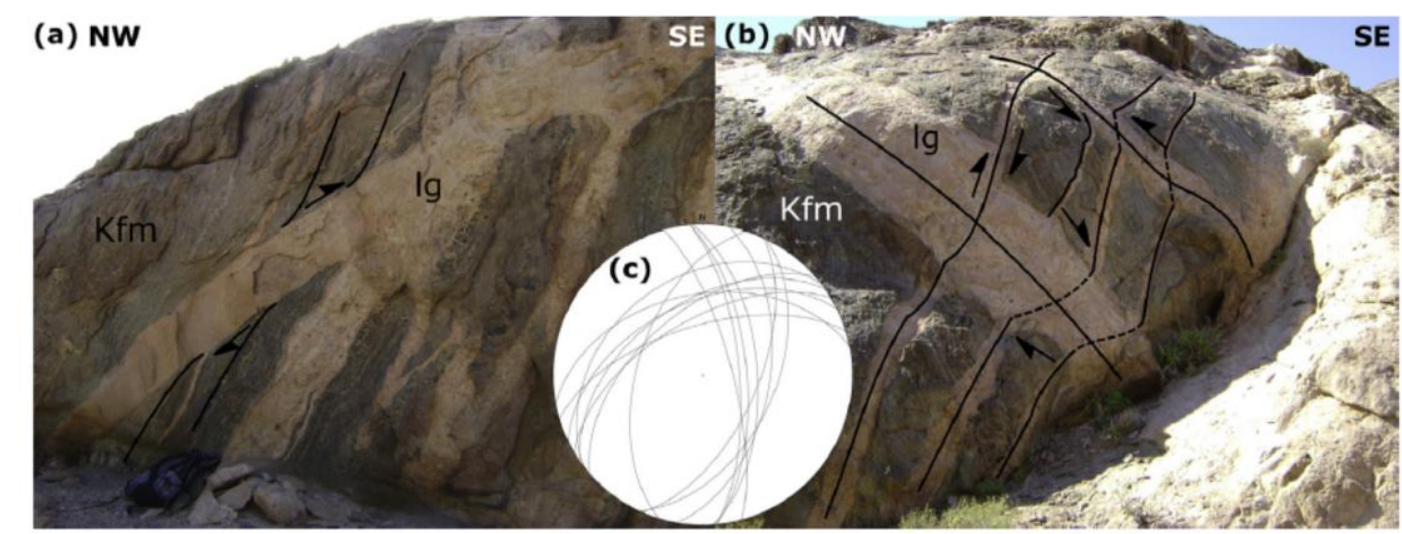

Fig. 6. Set 1b leucogranites, subset of main Set 1. (a) Cross-sectional view (to the NE) of the conjugate Set 1b leucogranites in gneisses of the Khan Formation. Top-to-the-SE displacement is indicated by the wall-rock drag; (b) cross-sectional view of conjugate Set 1b indicating top-to-the-SE displacement in NW-dipping sheets, whereas SE-dipping sheets indicate top-to-the-NW displacement; (c) lower hemisphere, equal area projection of the conjugate Set $1 \mathrm{~b}$ leucogranites $(\mathrm{n}=15$ ). Note that the intersection between the two leucogranite sets is roughly parallel to the plunge of the HD. Kfm = Khan Formation (xenoliths); $\mathrm{lg}=$ leucogranite sheet.
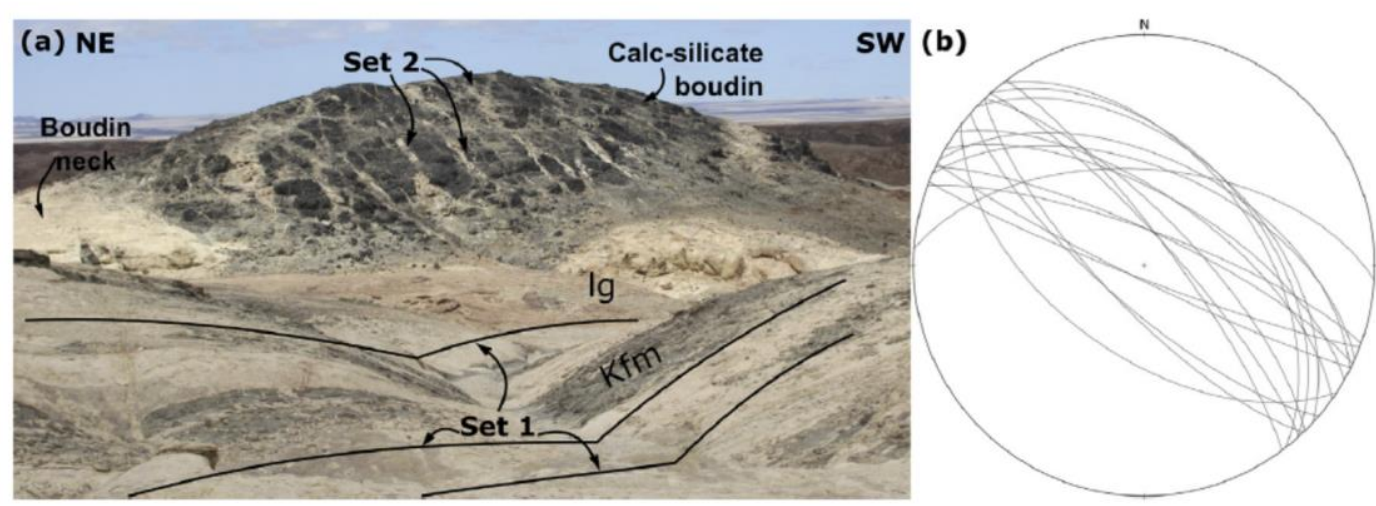

Fig. 7. (a) Large-scale boudin of the calc-silicate layer (black) intruded by Set 2 leucogranite sheets dipping at high angles. The granite sheets dipping at high angles form closely spaced sets in the competent calc-silicate felses and are parallel to NW-trending granite-filled interboudin spaces on either side of the boudin. Field of view in the middle ground is $\sim 100 \mathrm{~m}$ (b) Lower hemisphere, equal area projection of Set 2 leucogranites $(n=18)$ illustrating the orientation of the granite sheets at high angles to the $F_{2}$ fold hinge. Kfm $=K$ Khan Formation (xenoliths); $\lg =$ leucogranite sheet.

leucogranites show steep to subvertical fold plunges and northeasterly trending axial planes, parallel to $F_{2}$ folds.
3.3.3. Set 3 leucogranites

A third, distinct set of subhorizontal leucogranite sheets (Set 3) 

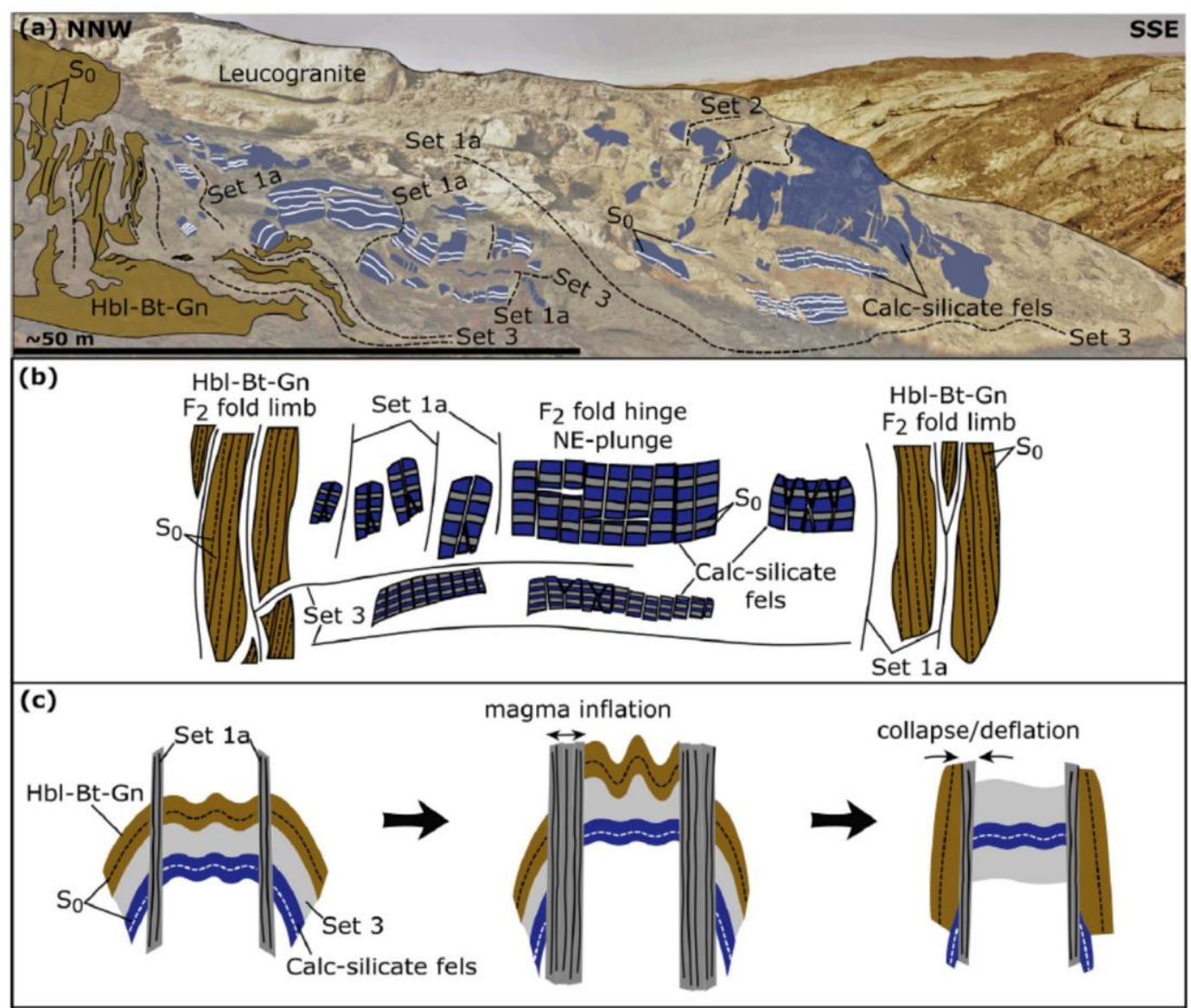

Fig. 8. (a) Photograph and (b and c) annotated line drawings of the $\sim 30 \times 100 \mathrm{~m}$ vertical cross-section of a cliff in the central parts of the angular, box-shaped HD hinge zone that records the intense disruption of the wall-rock sequence. The central calc-silicate raft is bounded on either side by subvertical, NE-trending hornblende-biotite gneisses. Layer continuity is lost between the central hinge and subvertical limbs. Shallowly dipping, bedding-parallel Set 3 granite sheets form the base of the massive calc-silicate fels. NEtrending, subvertical Set 1a leucogranites intrude and anastomose around the gneisses parallel to the axial plane of the first-order fold. The schematic diagram in (c) illustrates a tentative sequence of events that led to the development of the angular, box-shaped fold. Legends for lithology is the same as those shown for Fig. 4.

is present, but rare, probably also as a result of the lack of topography that would expose the flat lying sheets. Set 3 leucogranites cut the subvertical wall-rock gneisses at high angles. Where developed, the shallowly-dipping sheets typically show limited strike extents with either abrupt terminations against wall-rock fragments or rotating and seemingly merging with Set 1 leucogranites (Fig. 8a). In places, Set 3 granites are gently folded into upright, north-easterly trending folds, parallel to regional $F_{2}$ folds, indicating their emplacement during continued regional northwest-southeast directed shortening $\left(\mathrm{D}_{2}\right)$.

\subsubsection{Outer granite envelope}

The outer leucogranite envelope is between 200 and $300 \mathrm{~m}$ wide. Most of the granites are very coarse grained or pegmatitic with up to $15 \mathrm{~cm}$ large feldspars. A weak, north-easterly trending solid-state foliation defined mainly by flattened quartz discs, is only locally developed. The granites are particularly massive on the south-eastern limb of the HD, where they are overridden by the overlying Arcadia thrust (Figs. 2-4). Wall-rock xenoliths are rare and include both marbles of the overlying Rössing Formation and calc-silicate felses of the Khan Formation. This corresponds to the position of the massive granites along the contact between the Khan and Rössing Formations. The outer granite envelope, thus, overlies the central granite injection complex of the HD. Individual granite sheets can still be distinguished in the outer granites, particularly along the north-western limb of the HD. Here, the granite sheets show mainly north-easterly trends parallel to the Set 1 leucogranites in the central parts of the HD. Nevertheless, the strongly sheeted nature of leucogranites in the core of the HD is lacking in the outer granite envelope.

\subsection{Disruption of wall rocks}

For the most part, original bedding and/or structures in adjacent wall-rock fragments cannot be traced across granite sheets. This mismatch and displacement of wall rocks is most prominent in the hinge of the HD (Figs. 8 and 13). Here, large (up to $80 \times 120 \mathrm{~m}$ ) rafts of the calc-silicate marker layer can be found some 150 and up to $600 \mathrm{~m}$ to the northeast of the north-eastern first-order hinge of the dome (Figs. 4 and 13a). The displaced wall-rock rafts are intruded and enveloped by north-easterly-trending anastomosing leucogranite sheets or are embedded in more massive granite. The competent calc-silicate felses appear structurally featureless, but interlayered hornblende-biotite gneisses and schists are tightly crenulated $\left(\mathrm{F}_{2}\right)$ and carry a shallow north-easterly-plunging rodding lineation, parallel to the regional $\mathrm{L}_{2}$ lineation. This suggests no 

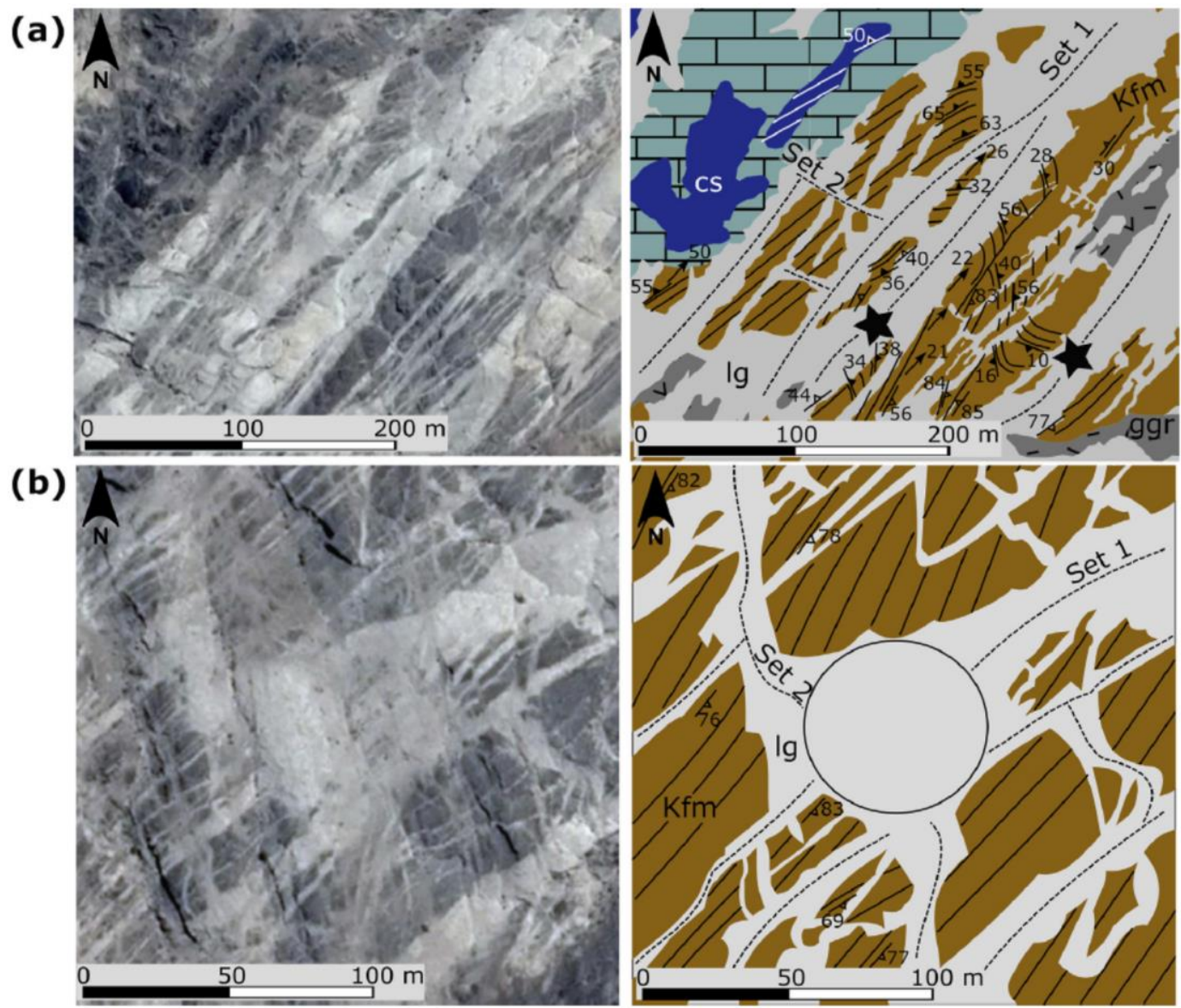

Fig. 9. (a) Google Earth image and geological map illustrating Set 1a leucogranites intruding parallel to the axial plane of a parasitic M-fold in the central parts of the HD (see Fig. 4 for location). The structural form lines in wall rocks indicate that the structural integrity is maintained across the $\sim 10 \mathrm{~m}$ wide granite sheets. In the south-westem parts of the NEplunging $\mathrm{M}$-fold (indicated by stars), bedding is sharply truncated by the axial planar (Set 1a) sheet and the form lines in wall-rock fragments on either side of the granite sheet cannot be matched, suggesting some wall-rock displacement; (b) Google Earth image and corresponding geological map showing the high-angle intersection between Set 1a and Set 2 . This intersection results in the formation of a larger granite blow where Set 1a terminates against the Set 2 sheet and shows no continuation beyond the granite blow. resulting in a T-shaped intersection. It also illustrates the inconsistent contact relationships, i.e. cross-cutting and interconnectivity and thus, the protracted intrusion of the leucogranite network within the HD. Legends for lithology is the same as those shown for Fig. 4. $\mathrm{Kfm}=$ Khan Formation (xenoliths); cs = calc-silicate fels; $\mathrm{lg}=$ leucogranite sheet; ggr = grey granite (xenoliths).

or only minor rotation of the rafts despite the considerable lateral displacement (Fig. 13).

A prominent $(\sim 30 \times 100 \mathrm{~m})$ cliff section in the central parts of the HD hinge zone provides 3D exposure of a disharmonic fold structure that records the complete disruption of the wall-rock sequence (Figs. 8 and 13b). Interlayered calc-silicate felses, marble and minor biotite gneisses of the Khan Formation form a shallowly northeast-dipping, only gently folded raft in the central parts of the cliff. The mainly calc-silicate felses are intruded and brecciated by leucogranite. Shallowly-dipping, bedding-parallel granite sheets form the base of the massive calc-silicate fels. Despite the brecciation through granites, the marker layer maintains stratigraphic continuity over a length of $\sim 120$ m with only minor rotation and displacement of smaller fragments (Figs. 4, 8 and 13). This central calc-silicate raft is bounded on either side by subvertical, north-easterly-trending, banded hornblende-biotite gneisses (Figs. 8 and 13). The gneisses are, in turn, intruded and bounded by north-easterly trending anastomosing leucogranite sheets, parallel to the axial plane of the fold and the first-order HD. The loss of any layer continuity between the central hinge and the subvertical limbs of the angular fold suggests the excision of strata and removal of stratigraphy. This results in an angular, box-shaped fold with highly discordant and truncated stratigraphy (Figs. 8 and 13).

A similar displacement of wall-rocks across intrusive granite sheets is more difficult to demonstrate in the central parts of the $\mathrm{HD}$ due to the lack of prominent marker horizons and the predominantly steep dips and north-easterly trends of hornblendebiotite gneisses parallel to the limbs of the fold. The disruption and lateral displacement of wall rocks is evident where leucogranites have intruded the hinges of parasitic $\mathrm{F}_{2}$ folds (Fig. 9a). In the central parts of the area shown in Fig. 9a bedding form lines seem continuous and original $F_{2}$ folds maintain structural integrity across the up to $10 \mathrm{~m}$ wide leucogranite sheets. In this case, bedding form lines between adjacent wall-rock fragments outline shallow $\left(15-25^{\circ}\right)$ north-easterly plunging $\mathrm{M}$-folds in the first-order hinge of the HD. This structural continuity is lost across wider sheets as indicated by the stars in Fig. 9a. Here, the hinge of a north-easterly plunging fold is sharply truncated by axial planar leucogranite sheets and bedding form lines cannot be matched in Khan 


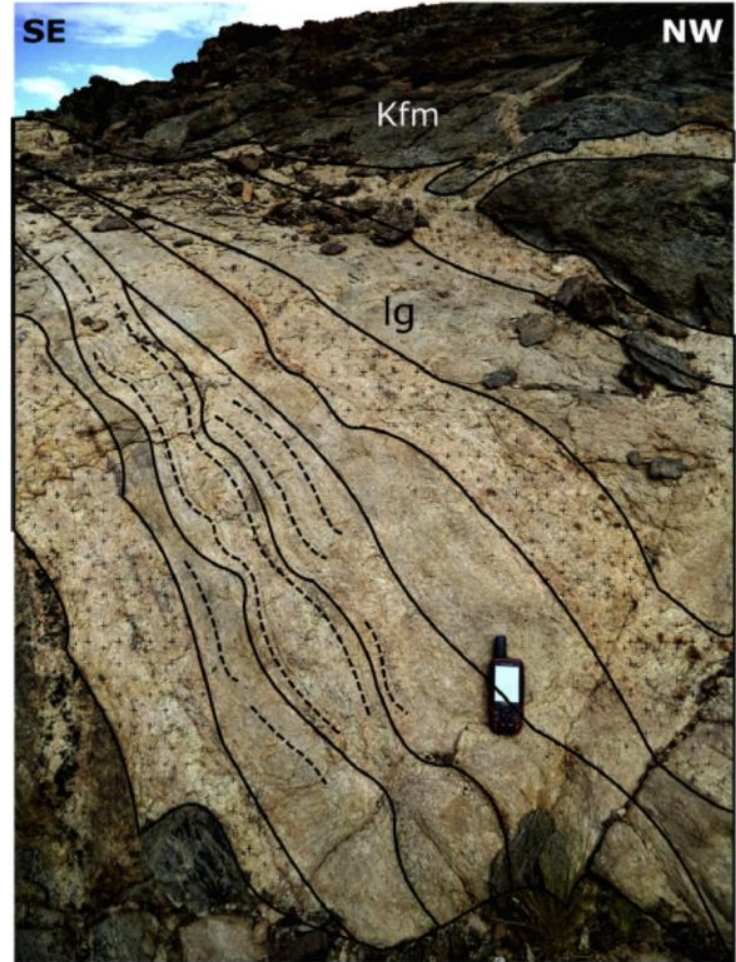

Fig. 10. Oblique view to the SW of a Set 1a granite sheet comprised of several compositionally and texturally distinct smaller sheets (annotated). The intrusive contacts and low-angle truncation between internal sheets (solid lines) illustrate the successive emplacement of sheets. Layer- and $S_{2}$-parallel solid-state foliation (dashed lines) and layer-parallel boudinage document the different degrees of postemplacement deformation and the different emplacement times of granite sheets during $\mathrm{D}_{2}$ shortening. $\mathrm{Kfm}=$ Khan Formation; $\mathrm{lg}=$ leucogranite sheet.

Formation gneisses on either side of the granites. Despite the disruption of the wall-rocks by granites, regional structures retain their orientation indicating no or only little rotation of the wallrock fragments.

\subsubsection{Wall-rock contacts}

Granite wall-rock contacts are typically sharp and clearly intrusive. Locally developed horn structures projecting from the outer edge of granite sheets into wall rocks underscore the intrusive nature of the sheets. However, many contacts also show evidence of a wall-rock deflection (Fig. 14a). The deflection of wall rocks is most pronounced for Set 1a leucogranites. Numerous, though not all, leucogranite sheets are bounded by sigmoidal foliation patterns on either side of particularly narrower sheets. In places, only one wall-rock contact is deflected. In cases where a deflection of wall rocks can clearly be discerned, a dextral sense of shear is indicated along Set 1a leucogranites (Figs. 13 and 14a). Similarly, Khan Formation xenoliths or screens commonly show sheared and sigmoidal foliation patterns, resembling S-C' structures also pointing to a dextral sense of shear (Fig. 14b). Foliations in the leucogranites, in contrast, record largely coaxial flattening normal to the sheets rather than the non-coaxial deformation indicated by the wall-rock deflection. A deflection of wall-rock bedding is also recorded along some of the conjugate Set 1b granites (Fig. 6a-b). When viewed parallel to the line of intersection between the two sets, the wall rock drag mostly indicates a top-to-the-southeast dip-slip displacement along the north-

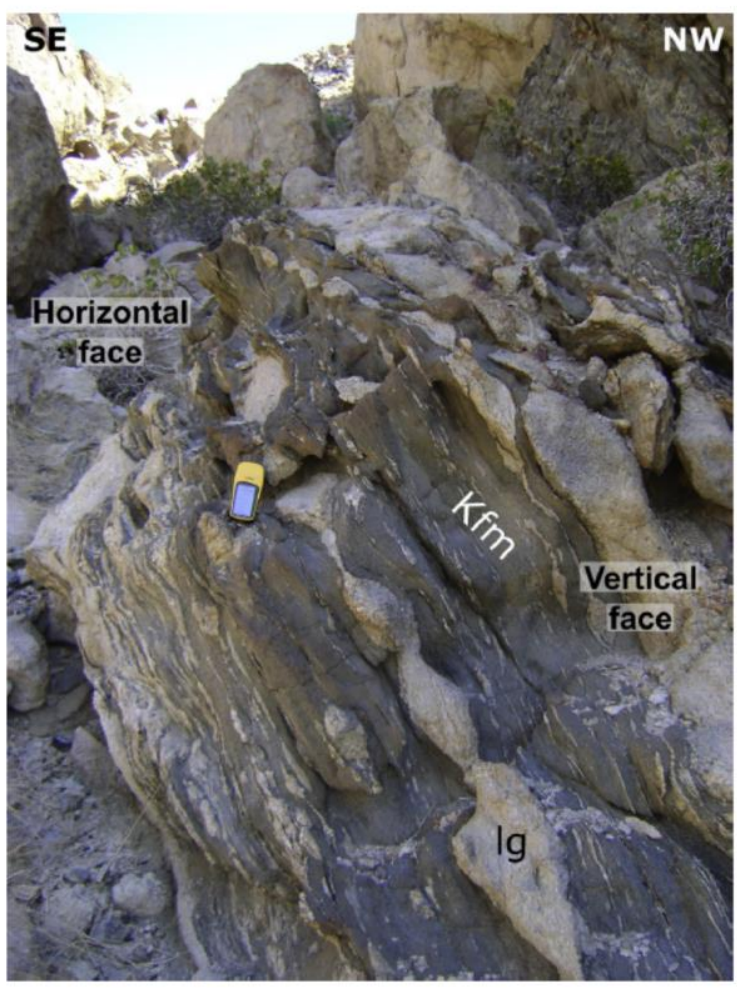

Fig. 11. Field photograph showing NE-trending Set 1a granite sheet displaying chocolate-tablet pinch-and-swell and boudinage indicating a large component of layer-normal coaxial shortening after emplacement of the granites. $\mathrm{Kfm}=$ Khan Formation (xenoliths); $\lg =$ leucogranite sheet.

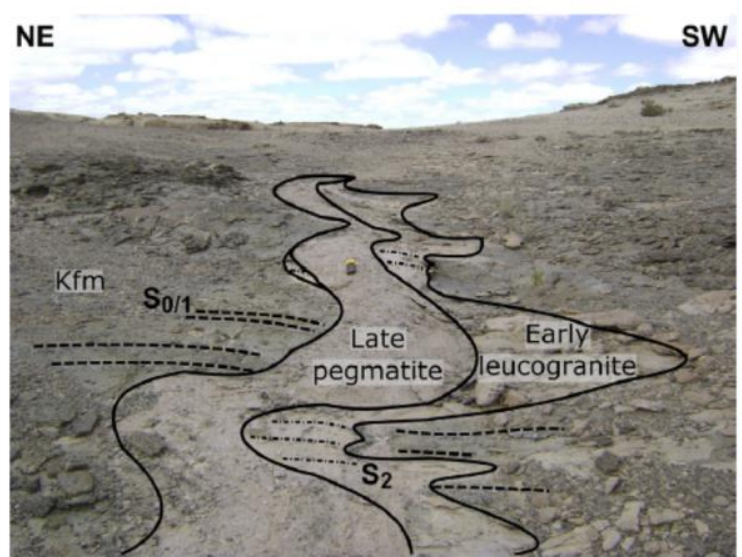

Fig. 12. Multiple intrusive relationships in Set 2 leucogranite sheets. The earlier, more tightly folded sheet is cross-cut by a later, only gently-folded granite sheet. A weakly developed NE-trending, axial planar solid-state foliation (shown by dashed lines) defined by flattened quartz discs or grain-shape preferred orientation of mafic mineral grains, is axial planar to folded Set 2 granites and parallel to the $S_{2}$ in wall rocks. $\mathrm{Kfm}=$ Khan Formation.

westerly dipping set and an opposite top-to-the-northwest sense of shear along the southeast-dipping set (Fig. $6 a-b$ ). The sense of shear along the conjugate granite sheets, thus, points to a bulk northwest-southeast directed shortening, despite the fact that the direction of shortening intersects the obtuse instead of the acute 


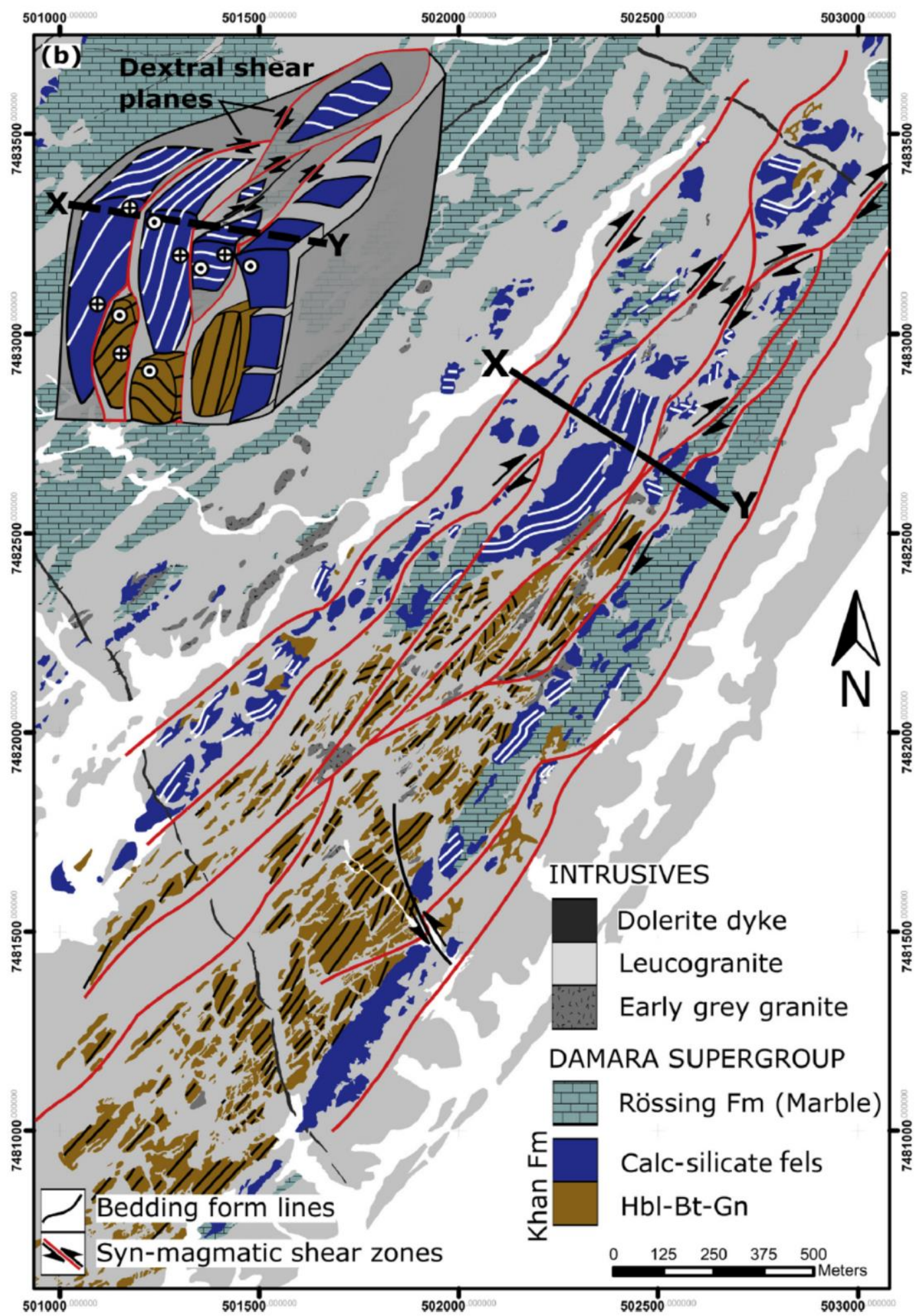

Fig. 13. (a) Simplified form line map of the HD, highlighting the presence and lateral displacement of the calc-silicate marker fels along syn-magmatic shear planes following the undulating, broadly axial planar leucogranite sheets (Set 1a). Inset (b): schematic block diagram illustrating the juxtaposition and distinct spacing of wall-rock fragments along and across-leucogranite sheets also seen in the field photograph in Fig. 8a. This underlines the breccia-like textures of wall-rocks in the HD and the, at least local, loss of magma (volume) during granite sheeting and associated deformation. 


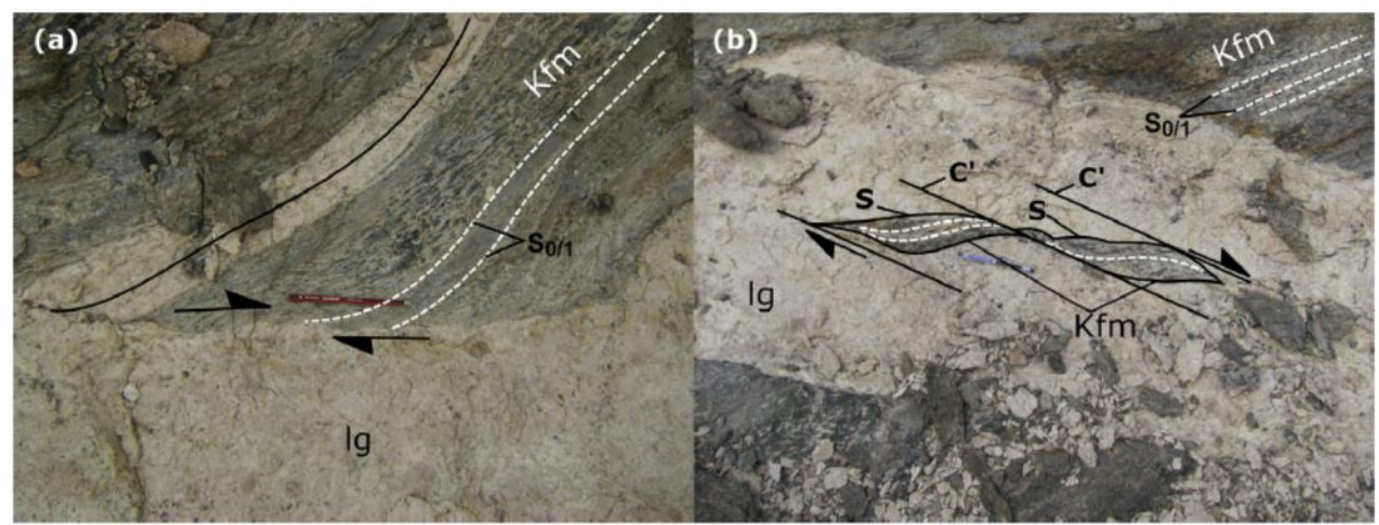

Fig. 14. (a) Dextral sense of shear illustrated by wall-rock drag along a Set 1a leucogranite sheet (plan view); (b) Khan Formation xenoliths or screens within a Set 1a sheet showing sheared and sigmoidal foliation patterns, resembling S-C structures also pointing to the emplacement of the main Set 1a leucogranites along and into non-coaxial shear zones with a consistent dextral sense of displacement. $\mathrm{Kfm}=$ Khan Formation (xenoliths); $\mathrm{lg}=$ leucogranite sheet.

angles of the conjugate sets. Ismat (2015) suggested that the dihedral angle between conjugate shear zones increases with increasing confining pressure and similar findings have been reported by Symington et al. (2014) where the direction of maximum shortening intersects the obtuse angle between conjugate shear zones. The north-westerly strike of Set 2 granites, at a high angle to the regional stretch $\left(\mathrm{L}_{2}\right)$, and parallelism of these granite sheets to interboudin spaces in the outer calc-silicate layer suggest an emplacement of the granites into extensional (mode I) fractures (Fig. 7). In contrast, hornblende-biotite gneisses in the core locally show a drag of the wall-rock bedding against Set 2 granites that consistently points to a sinistral sense of shear along the granites. We have not been able to identify any wall-rock deflection or internal shear sense indicators along or within Set 3 leucogranites.

\subsection{Cross-cutting relationships and relative timing of leucogranites}

Numerous contacts between different leucogranite sets show the truncation and/or displacement of earlier sheets by later granites. These clearly cross-cutting contacts are common, but they are inconsistent between different sets across the HD. This suggests the broadly contemporaneous emplacement of different granite sets. More commonly, however, contacts show compositional and textural continuity across intersections. This also points to the coeval emplacement of and connectivity between intersecting granite sheets. The connectivity between different leucogranite geometries is particularly evident on a map scale (Fig. 9). There are numerous places in the HD where intersections between different leucogranite sets are marked by large (up to $80 \times 100 \mathrm{~m}$ ), irregularor rhomb-shaped granite pods or blows. These granite blows occur along the low-angle intersections of undulating Set 1a leucogranites, or high-angle intersections between Set 1a and northwesttrending Set 2 leucogranites (Fig. 9b). In the latter case (Fig. 9b), the prominent Set 1a leucogranite sheet terminates in the granite blow and has no continuation beyond the resulting T-shaped intersection. Rhomb-shaped granite blows between en-echelon Set 1a leucogranites point to their location in dilational jogs, corresponding to the dextral strike-slip displacement along Set 1a granites (Fig. 15). There are not sufficient field observations that could firmly corroborate cross-cutting relationships of Set 3 leucogranites with the subvertical to steeply dipping Sets $1 \mathrm{a}, 1 \mathrm{~b}$, and 2 . Overall, the inconsistent contact relationships, both cross-cutting and interconnected, underline the protracted intrusion of granite sheets and the at least temporary connectivity between different granite sets.

The main Set 1-3 leucogranites sharply cross-cut the subvertical bedding in the HD. This would suggest the intrusion of the granite sets into an upright and tight fold and a relatively late emplacement during $F_{2}$ folding. However, most granite sheets have also been affected by $D_{2}$ strains (see also Longridge, 2012). The granites show formation of a layer- and $S_{2}$-parallel solid-state foliation (Fig. 10) and layer-parallel boudinage (Fig. 11) in Set 1a granites, and folding of Set 2 leucogranites parallel to the northeast-trending regional $F_{2}$ (Fig. 12). This corroborates the syn-to late $F_{2}$ timing of granite emplacement and probably during the fold lock-up stage of the HD. The highly variable fabric development and boudinage and/or folding underlines the successive emplacement of the granites that track late-stage $D_{2}$ strain increments. These findings are consistent with observations by Druguet and Hutton (1998) that documented syn-tectonically emplaced granites with a similar deformation history in Cap de Creus, Spain.

\section{Discussion}

\subsection{Folding and initial magma accumulation}

The intrusion and progressive deformation of the leucogranite sheets in the HD document the syn-to late-tectonic emplacement of the granites during largely coaxial northwest-southeast directed shortening. This corresponds to the regional $\mathrm{D}_{2}$ deformation and upright folding $\left(\mathrm{F}_{2}\right)$ of the basement-cover sequence in the Damara belt (Jacob, 1974; Oliver, 1994; Poli and Oliver, 2001; Kisters et al., 2004, 2012; $D_{3}$, after Miller, 1983, 2008; Longridge et al., 2011; Longridge, 2012). In the lower parts of the Damara Supergroup, $F_{2}$ folding is associated with the formation of detachment folds, particularly where rheologically weaker rocks allow for easy slip along the detachment surface. For example, in the Rössing Formation, detachment horizons are commonly located in marble units. The base of the HD is not exposed, but an origin as a detachment fold is likely given the shallow-to moderate $\left(25-45^{\circ}\right)$ dips of the basement-cover contact around the central Ida basement dome, but typically subvertical dips of the isoclinally folded, overlying Damara Supergroup (Fig. 3). These geometric constraints and strain incompatibility necessitate the formation of a detachment fold. Importantly, the leucogranites intruded into hot (T $\sim 700-750{ }^{\circ} \mathrm{C}$; Jung and Mezger, 2003) suprasolidus wall rocks in this part of the sCZ. At these conditions the granitic magmas may have contained as much as $40-50 \%$ melt (e.g., Clemens and Wall, 

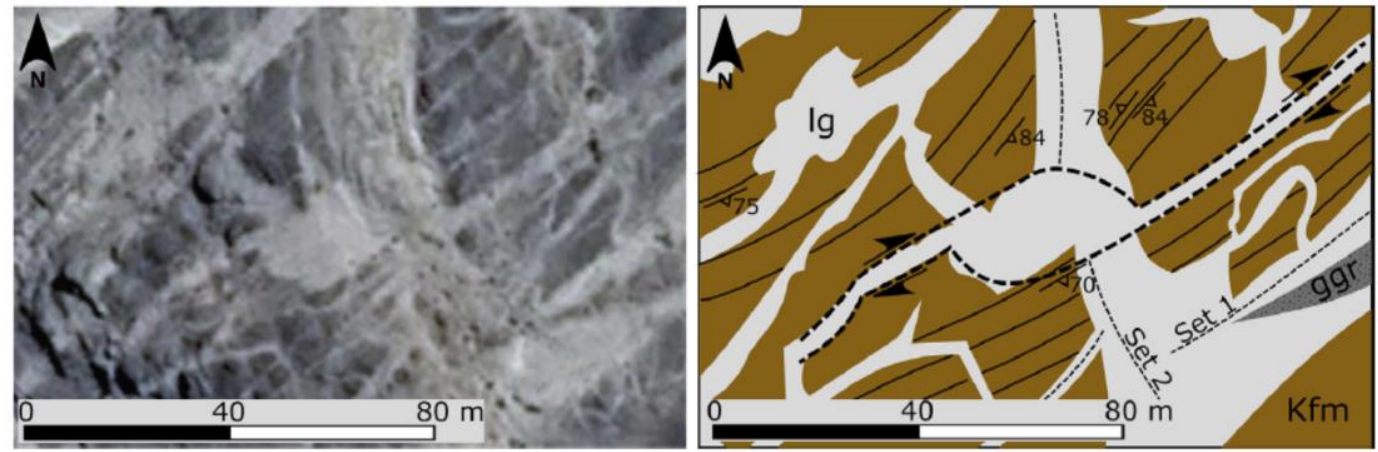

Fig. 15. Google Earth image and geological map showing Set 1a leucogranites forming rhomb-shaped granite blows in a right-stepping offset between en-echelon sheets. The location of the granite blow corresponds to a dilational jog geometry given the dextral sense of shear along Set 1a leucogranites. Kfm = Khan Formation (xenoliths); $\lg =$ leucogranite sheet; ggr = grey granite (xenolith).

1981). This implies the presence of a low-viscosity melt phase for a protracted period, as long as the granites and their wall rocks remained at temperatures above the granite solidus of $\sim 645^{\circ} \mathrm{C}$ (Johannes, 1984). The voluminous leucogranites along the basement-cover contact are, thus, likely to have promoted slip and detachment folding along the basal detachment surface (Fig. 16a-b).

The strain incompatibility that arises during folding and fold amplification above the detachment creates dilatancy in the core of the fold. The resulting pressure gradient drives magma from the detachment and surroundings of the HD into the core of the fold, corresponding to a dilatancy or tectonic pumping effect (Fig. 16a-b) (Etheridge et al., 1984; Sibson, 1996; McCaig et al., 2000). This stage represents an initial phase of lateral magma segregation and accumulation in the core of the HD, above the basement-cover contact (Fig. 16b-c). Importantly, sheet-like leucogranite complexes such as that of the HD are typically hosted by antiformal structures in the SCZ (Miller, 2008; Kisters et al., 2009). Adjoining synforms show markedly fewer, if any, granite sheets. This contrast is exemplified by the Arcadia Syncline to the immediate east-northeast of the HD (Figs. 2 and 3) where Khan Formation rocks infolded into underlying basement gneisses contain hardly any leucogranite. This feature emphasizes the significance of localized dilatancy as a result of strain incompatibilities for the lateral transfer and accumulation of magmas during folding and the amplification of antiforms, in particular.

\subsection{Melt segregation from magma accumulation sites}

Further shortening and tightening of the HD will lead to magma compaction and expulsion of the intergranular melt, resulting in a more closely packed crystal framework (Fig. 16c-d) (e.g., Rushmer, 1995; Vigneresse et al., 1996; Rosenberg and Handy, 2005; Reichardt and Weinberg, 2012; Sawyer, 2014; Weinberg et al., 2015; Carvalho et al., 2016). The melt phase segregates from the magma into smaller, mainly dilatant veins. Further segregation of the melt is driven by differential stresses and, eventually, the buoyancy of the melt, once larger volumes have accumulated into veins or granite sheets (Davidson et al., 1994; Sawyer, 2000; Bea et al., 2005). This stage corresponds to the injection and emplacement of the fractionated leucogranite sheets into the higher parts of the HD (Fig. 16c-d). Melt segregation during the tightening of the fold is corroborated by the late-stage timing of granite emplacement when the HD had already assumed an upright orientation and tight geometry. The large number of individual magma sheets contained in the HD illustrates the episodic expulsion of the melt that is likely related to the progressive tightening of the fold (Fig. 16c-d). Since the rates of fold amplification determine the rate and frequency of granite injections, the commonly slower tectonic rates are compatible with the typically higher rates of granite emplacement. The result will also be a range of melt compositions, depending on the degree and timing of melt segregation (e.g., Bea et al., 2005; Carvalho et al., 2016), as is suggested by the range of compositions and highly variable textures of even adjacent granite sheets in the HD.

\subsection{Controls of leucogranite networks}

A similar sequence of processes involving the stepwise segregation and accumulation of magmas in fold hinges, followed by the expulsion of melt was described in the analogue models by Barraud et al. $(2001,2004)$. The experiments document the distribution and flow of a mobile paraffin phase in layered wax models during coaxial shortening and folding of the layered sequence. Notably, Barraud et al. (2004) distinguish a so-called "active" from a "passive" migration of the mobile phase (melt) in veins and vein networks. Active migration (Barraud et al., 2004) describes the movement of the mobile phase due to its intrinsic properties, namely buoyancy and its lower viscosity. In the models, active migration only plays a subordinate role for the redistribution of the mobile phase. Instead, the passive mode of migration predominates. Passive migration describes the migration of the mobile phase through a vein network that is principally determined by the far-field stress and strain and strain-rate variations during folding from initial buckling, through to fold amplification and eventual fold lock up.

This agrees with the fact that the orientation of the three main granite sets in the HD is geometrically related to the orientation of the first-order fold and regional stresses. The dominant Set 1a leucogranites intrude broadly parallel to the axial plane of the HD and at high angles to the regional shortening, whereas Set 2 and 3 leucogranites are normal to the axial plane. Syn-kinematic granite stringers or leucosomes emplaced parallel to the axial planes of folds are a widely documented feature of many high-grade metamorphic terrains worldwide (e.g., Sawyer, 1998). The emplacement of Set 1a granites in the axial planar orientation implies dilation of the sheets in the plane of flattening and against the direction of shortening during folding. This is problematic and the origin of axial planar granites remains a puzzling feature, although a number of different mechanisms have been postulated to account for their occurrence (e.g., Hand and Dirks, 1992; Brown and Solar, 1998; comprehensive review in Vernon and Paterson, 2001; Weinberg 

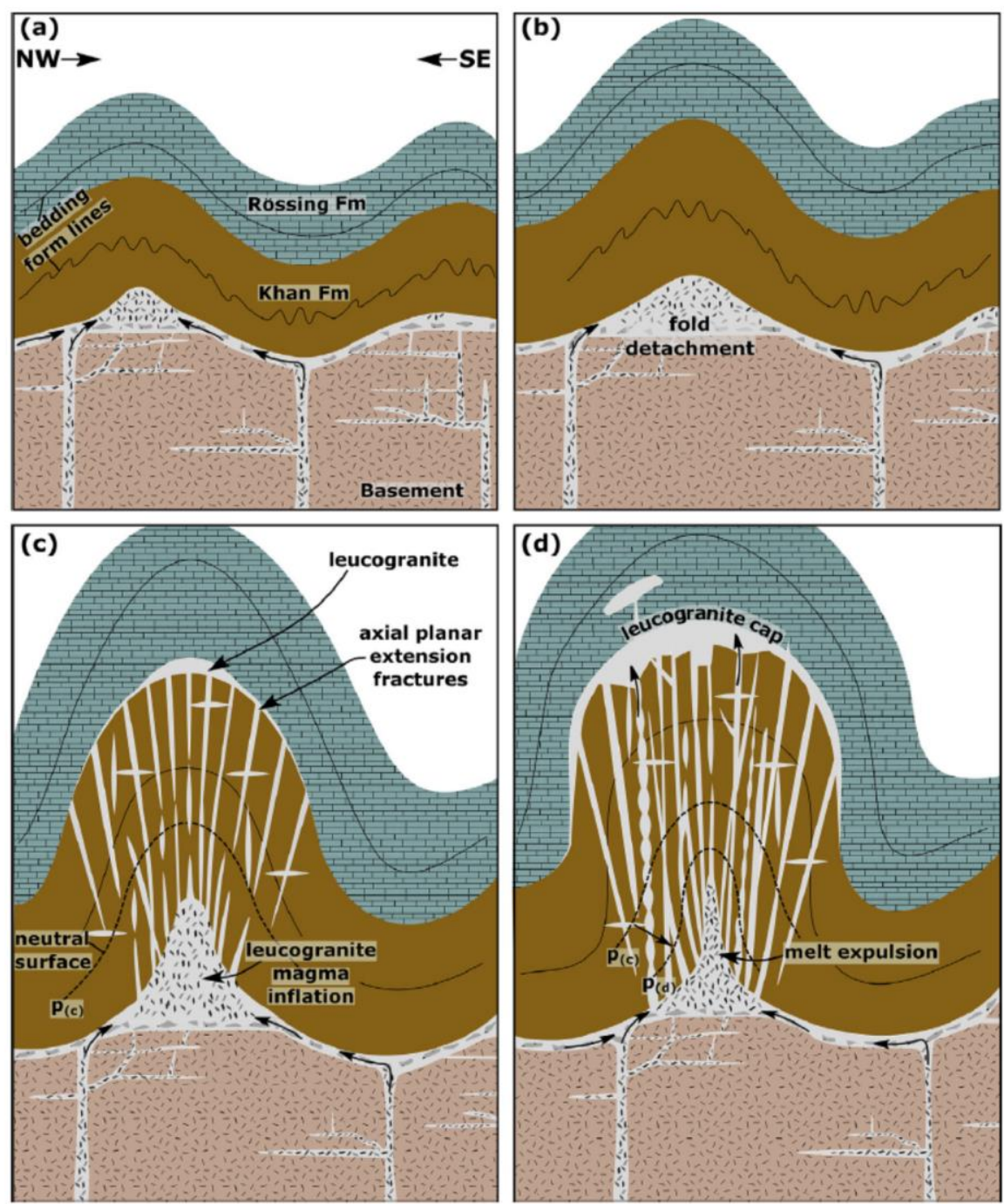

Fig. 16. Schematic sketches illustrating the envisaged progressive evolution of the HD injection complex from (a) the amplification of disharmonic detachment folding of the Khan Formation and HD above the magma-lubricated basement-cover contact, via (b) lateral segregation of basement-derived magmas, particularly along the basement-cover interface, and accumulation of magmas in the core of the fold. This magma accumulation results in (c) fold inflation and coeval tightening of the fold causes extension in the outer arc forming axial planar extension fractures. Compaction-driven mobilization of a melt phase from the magma occurs via these fractures (corresponding to Set 1), corresponding to the injection of fractionated melts into the higher parts of the HD. (d) Further fold tightening and fold lock-up leads to the formation of the main injection complex, made up of thousands of smaller melt batches that are repeatedly expelled from magmas in the core of the fold. The melt-bearing leucogranite sheets assist in accommodating the regional shortening. leading to the relative displacement of wall rocks, but with little rotation or large-scale dismemberment. The overlying ductile marble units of the Rössing Formation result in the arrest of the magmas and pooling of the granites to form the up to $300 \mathrm{~m}$ wide granite envelope above the injection complex and at the base of the marbles. (c-d) The neutral surface of the fold is indicated by the dashed line; $p_{(c)}$ and $p_{(d)}$ denote the position of the neutral surface in Fig. 16c and d, respectively. Note the migration of the neutral surface towards the inner arc as the fold progressively tightens due to tangential longitudinal strain (Ramsay, 1967; Bobillo-Ares et al., 2000).

and Mark, 2008; Weinberg et al., 2015). In the HD, the currently outcropping parts expose the crestal region of the fold. Assuming that folding was accommodated by a component of tangential longitudinal strain the outer arc of the fold is likely to have experienced a component of layer-parallel stretch normal to the fold axial plane (Ramsay, 1967; Dieterich, 1969; Hudleston and Treagus, 2010). This may explain the abundance of axial planar Set 1a leucogranites that intrude the competent Khan Formation gneisses normal to the direction of the outer arc extension (Fig. 16c-d). Importantly, the analysis of the strain distribution in folds deformed by tangential longitudinal strain also suggests the migration of the neutral surface that separates outer-arc extension from inner-arc shortening towards the inner arc of the fold during progressive fold amplification (Bobillo-Ares et al., 2000). This would increase the region experiencing outer-arc stretch in the fold profile during fold tightening (Fig. 16c-d). Repeated sheeting in Set 1a leucogranite may, thus track the incremental tightening and fold amplification.

The drag of the wall-rock foliation and displacement of wall rocks along Set $1 \mathrm{a}$ leucogranites point to a consistent dextral sense of displacement and an additional non-coaxial component of deformation along the leucogranite sheets (Figs. 13 and 14). In contrast, solid-state fabrics in the leucogranites and the symmetrical and commonly chocolate-tablet-type boudinage of Set 1a leucogranites (Fig. 11) suggest the coaxial shortening normal to the sheets (Fig. 17). We interpret this to reflect a switch in leucogranite 


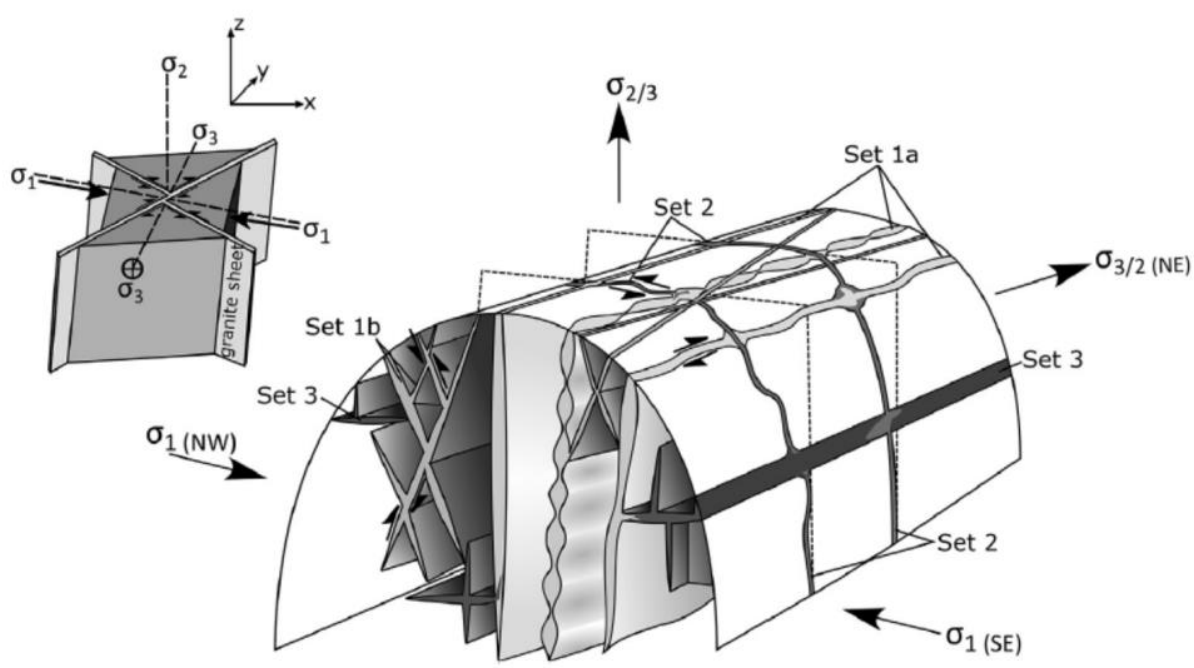

Fig. 17. Schematic sketch illustrating the orientation, geometry and displacement recorded along the main leucogranite sheets and their significance for deformation of the HD; see text for detailed discussion. Progressive NW-directed subhorizontal shortening beyond the fold lock-up stage is accommodated through dextral shear and lateral displacement of the HD stratigraphy along axial planar Set 1a sheets, vertical stretch accommodated along Set 3 and conjugate Set $1 \mathrm{~b}$ sheets, and hinge-parallel stretch along Set 2 sheets.

rheology during and following the intrusion and crystallization of the granite sheets. Initially melt-bearing and, thus, weaker leucogranites localize the non-coaxial component of the bulk strain (e.g., Vigneresse et al., 1996). Strain localization is into the melt phase, but the melt has no strain memory. In other words, noncoaxial fabrics related to the dextral shearing remain unrecorded in the leucogranites and are only recognized by the wall-rock deformation adjacent to the granite sheets (Fig. 14). Upon full crystallization or expulsion of the melt, the folding and/or boudinage of leucogranite sheets indicates their competency compared to the wall-rock gneisses (Fig. 11). During this stage, the leucogranites record the coaxial component of the bulk strain and solidstate fabrics and the chocolate-tablet boudinage only document the layer-normal shortening of the sheets. The consistent dextral sense of displacement points to the pure-shear dominated, yet slightly oblique and dextral transpressional shortening during $\mathrm{D}_{2}$ (Figs. 13-15 and 17).

The orientation of Set 2 leucogranites broadly corresponds to extension fractures, normal to the regional stretch $\left(\mathrm{L}_{2}\right)$. However, the sinistral deflection of wall rocks indicates that Set 2 sheets are not emplaced into strictly extensional (mode I) fractures. Given the generally coeval timing of leucogranite sheets in the HD, the displacements along Set $1 \mathrm{a}$ and Set 2 defines a conjugate set of shear zones (Fig. 17). Deformation localization along the intersecting Set 1a and 2 leucogranites will thus result in the flattening of the fold through the combined effects of hinge-parallel stretch and hingeparallel translation of wall-rock fragments separated by granite stringers. The orientation and sense of shear along Set $1 \mathrm{~b}$ leucogranites (Fig. 6a-b) suggests that the conjugate set has accommodated subhorizontal shortening and vertical stretch, similar to the subhorizontal Set 3 leucogranites. In conjunction, both the orientation and the displacement along the intersecting leucogranite sets accommodate a subhorizontal, hinge-parallel and vertical stretch of the folded sequence during regional shortening $\left(D_{2}\right)$ (Fig. 17). The presence of an interconnected, three-dimensional leucogranite network has most likely resulted in the weakening of the wall-rock structure and a positive feedback between strain localization and melt-bearing zones (Hollister and Crawford, 1986; Vigneresse et al., 1996; Rosenberg and Handy, 2001, 2005; Weinberg and Mark, 2008). The late-kinematic emplacement of the granites is significant in that it illustrates strain localization and accommodation through the intrusive granites when the fold had reached the lock up stage.

\subsection{Permeability structure}

Zones of increased, directional permeability develop parallel to the intersections of two or more fracture sets (e.g., Sibson, 1996; Brown, 2010). Intersections between the Set 1a and Set 2 leucogranites are subvertical, whereas intersections between Set 1 (Sets $1 \mathrm{a}$ and $1 \mathrm{~b}$ ) and 2 and the shallowly-dipping Set 3 are subhorizontal and either parallel (Set 1a, 1b and 3) or normal (Set 2 and 3) to the fold hinge of the $\mathrm{HD}$ (Fig. 8a-b, 9 and 17). In addition, intersections of granite sheets within the conjugate Set $1 \mathrm{~b}$ are subhorizontal and parallel to the shallowly-plunging fold hinge of the dome (Figs. 6 and 17). The development of this permeability network critically depends on the connectivity between differently orientated fracture sets. Given that leucogranite sheets in the HD are almost invariably sheeted and made up of smaller, successively emplaced magma batches, intersecting sheets must have been melt bearing, at least temporarily, to have contributed to the permeability of the network. The formation of wider granite blows along intersections, abrupt terminations and T-shaped intersections between granite sets (Fig. 9b), or jog geometries between en-echelon granite sheets (Fig. 15) are likely candidates documenting the connectivity between high-angle granite sets. Most of these directional permeabilities are vertical and at a high angle to the inferred strike-slip kinematics along the main Set 1a leucogranites, and consistent with the predicted zones of focused fluid flow along shear zones (e.g., Sibson, 1996; Sibson and Scott, 1998). The orientation and geometry of the HD net-veined granite complex, thus, provides an interconnected lateral and vertical permeability network. Lateral permeabilities are suitably orientated to accommodate the segregation and accumulation of magma from a wider source region underlying the HD both parallel and normal to the fold hinge. Vertical permeabilities, particularly those of Set $1 \mathrm{a}$ and 2 granites and their intersections, are ideally suited for the vertical transfer of the magmas.

Despite the volume of granites and evident permeability structure, the first-order fold structure of the HD is relatively well 
preserved, with very little rotation of wall-rock fragments. This would suggest that the HD did not experience large-scale disruption during en masse flow of the wall rock - granite system. The relative structural coherence of the HD underlines the notion that the continuous segregation of smaller melt batches prevented the volume of melt from reaching the rheologically critical melt percentage of $\sim 25$ vol\% melt (e.g., Rosenberg and Handy, 2001, 2005). This prevented the breakdown of the solid-melt framework and led to the preservation of the first-order fold structure.

\subsection{The role of wall-rock lithologies for efficient melt transfer}

The parallel-sided, sheet-like geometry of leucogranites in the Khan Formation suggests high viscosity contrasts between the granitic magmas and wall rocks (e.g., Rubin, 1993). This emphasizes the competence of the Khan Formation gneisses that promotes the propagation of magma-filled fractures and sheet formation. In contrast, leucogranites are less abundant and have rather pod- or lens-like shapes in ductile marble-schist units of the overlying Rössing Formation (Fig. 16d). The higher ductility of marbles translates into a higher fracture toughness (e.g., Rivalta et al., 2015) and marble units tend to resist fracture propagation through ductile wall-rock deformation and dissipation of tensile stresses ahead of the melt-filled sheets (Hall and Kisters, 2016). These processes account for the commonly observed arrest of granite sheets upon entering marble units related to the blunting of magma-filled fractures along this lithological contact (Miller, 2008; Kisters et al., 2009). The leucogranites tend to pool along KhanRössing contacts. This scenario seems realized in the HD where the outer and internally massive granite envelope along the KhanRössing contact is underlain and fed by the granite injection complex in the core of the HD (Figs. 4 and 16d). In antiformal structures, the Rössing marbles effectively form a seemingly impermeable cap that inhibits further fracture-controlled ascent of the granitic magmas. The presence of only partially solidified granite sheets may lead to a similar fracture blunting and stalling of subsequently emplaced granite sheets (e.g., Miller et al., 2011). This promotes the lateral spreading and accumulation of subsequent granite batches in the crest region of the HD and within or below earlier emplaced granites. It would, thus, appear that the granite network of the HD has probably not contributed to the crustal-scale extraction of magmas. The granite injection complex rather records the accumulation, temporary storage and redistribution of magmas on the scale of hundreds of meters and possibly kilometres in this midcrustal section.

\section{Conclusions}

The kilometre-scale granite injection complex of the Holland's dome illustrates the significance of regional-scale folding for the lateral transfer, temporary accumulation and episodic segregation of granitic magmas and melts in the mid crust. Intrusive and timing relationships between leucogranites and folded wall-rock gneisses in the injection complex emphasize a number of points that seem pertinent for our understanding of magma transfer in general.

(1) The close association between the Holland's dome and leucogranite networks signifies the formation of regional gradients in magmastatic head during folding that are sufficiently large to guide and focus originally basementderived granites into the first-order fold. The main drivers of this early stage lateral magma transport are strain incompatibilities, namely dilatancy in the core of the upright antiform above a basal detachment. This leads to the initial accumulation of granite in the core of the antiform. This also implies the presence of, at least temporary, melt accumulation sites in these mid-crustal levels.

(2) The progressive tightening of the fold leads to magma compaction and the segregation and expulsion of intergranular melt phases from the melt-solid framework that intrude as mainly sheet-like leucogranites into the upper parts of the Holland's dome. This process of compactiondriven melt segregation during fold tightening and the advanced stages of folding agrees with the late-kinematic timing of granite injection into the tight, upright antiform.

(3) The preservation of wall-rock structures, but also internal contacts within and original geometries between intrusive leucogranite sheets illustrates the progressive assembly of the injection complex through successively emplaced, volumetrically small, but numerous (hundreds to thousands) magma batches. This highlights that magma segregation and transfer only involve small magma batches at any given time. Large magma volumes, such as those preserved in the Holland's dome, are the result of the amalgamation of many smaller magma batches. The field evidence agrees with experimental results that predict the mobilization and extraction of melt volumes significantly below the critical melt percentage (e.g. Rosenberg and Handy, 2005), thus maintaining structural coherence of the original wall-rock structures.

(4) The segregated magmas are injected as distinct, interconnected high-angle sets that provide a lateral and vertical plumbing system able to drain melt from the core of the fold. Strain localization into the melt-bearing leucogranite sets results in the overall weakening of the host structure and assists in the tightening of the fold beyond the fold lock up stage. The orientation of the intersecting leucogranite sets is closely related to the geometry of the fold and the regional stress field.

(5) The rates of fold amplification and tightening determine the rates and frequency of granite injections into the upper parts of the fold. The incremental granite sheeting ensures compatibility between the typically much lower tectonic strain rates and faster rates of granite emplacement.

(6) Despite the volume of granite, the Holland's dome injection complex has probably not contributed to a long-range magma transport through the crust. The spatial confinement of the injection complex to below the Khan-Rössing contact underlines the significance of rheological properties of wall-rock lithologies for magma transport that may promote or inhibit the fracture-controlled propagation of granitic magmas.

(7) The Holland's dome injection complex describes the deformation-driven and probably repeated segregation of a melt phase from earlier accumulated granitic magmas. This leads to the progressive fractionation of the magmas, which has ultimately also contributed to the generation of the uraniferous leucogranites in the region. An understanding of the structural setting and emplacement history of the leucogranites may, thus, be pertinent for an understanding of uranium mineralization.

\section{Acknowledgements}

This study presents part of the first author's MSc research. The authors would like to thank Swakop Uranium and the Husab Uranium Mine for their financial and logistic support and the permission to publish the results of this study. We thank Berti Roesener, Guy Freemantle and the geology department of Swakop Uranium for discussions and support during field work. TK thanks 
Deon Metjavi for being a reliable and trustworthy field assistant. We gratefully acknowledge the detailed and constructive journal reviews by Roberto Weinberg and Paul Bons and editorial comments and help by Toru Takeshita.

\section{References}

Allibone, A.H., Norris, R.J., 1992. Segregation of leucogranite microplutons during syn-anatectic deformation: an example from Taylor Valley, Antartica. I. Metamorph. Geol. 10, 589-600.

Barraud, J., Gardien, V., Allemand, P., Grandjean, P., 2001. Analog modelling of melt segregation and migration during deformation. Phys. Chem. Earth (A) 26 , 317-323.

Barraud, J., Gardien, V., Allemand, P., Grandjean, P., 2004. Analogue models of meltflow networks in folding migmatites. J. Struct. Geol. 26, 307-324. http:// dx.doi.org/10.1016/jsg.2003.06.002

Bea, F., Fershtater, G.B., Montero, P., Smirnov, V.N., Molina, J.F., 2005. Deformationdriven differentiation of granitic magma: the Stepninsk pluton of the Uralides, Russia. Lithos 81, 209-233.

Bobillo-Ares, N.C., Bastida, F., Aller, J., 2000. On tangential longitudinal strain folding. Tectonophysics 319, 53-68.

Bons, P.D., van Milligen, B.P., 2001. New experiment to model self-organized critical transport and accumulation of melt and hydrocarbons from their source rocks. Geology 29, 919-922.

Bons, P., Arnold, J., Elburg, M., Kalda, J., Soesoo, A., van Milligen, B., 2004. Melt extraction and accumulation from partially molten rocks. Lithos $78,25-42$. http://dx.doi.org/10.1016/j.lithos.2004.04.041.

Bons, P.D., Becker, J.K., Elburg, M.A., Urtson, K., 2010. Granite formation: stepwise accumulation of melt or connected networks? Earth Environ. Sci. Trans. R. Soc. Edinb. 100, 105-115, http://dx.doi.org/10.1017/S175569100901603X.

Brandt, R., 1987. A revised stratigraphy for the Abbabis complex in the Abbabis inlier, Namibia. South Afr. J. Geol. 90, 314-323.

Briqueu, L., Lancelot, J.R., Valois, J.P., Walgenwitz, F., 1980. Géochronologie U-Pb et genèse d'un type de minéralisation uranifere: les alaskites de Goanikontès (Namibie) et leur encaissant. bulletin centres recherches exploration production Elf. Aquitaine 4, 759-811.

Brown, M., 1994. The generation, segregation, ascent and emplacement of granite magma: the migmatite-to-crustally-derived granite connection in thickened orogens. Earth-Sci. Rev. 36, 83-130.

Brown, M., 2007. Crustal melting and melt extraction, ascent and emplacement in orogens: mechanisms and consequences. J. Geol. Soc. Lond. 164, 709-730.

Brown, M., 2010. The spatial and temporal patterning of the deep crust and implications for the process of melt extraction. Philosophical Trans. R. Soc. (A) 368 11-51. http://dx.doi.org/10.1098/rsta.2009.0200.

Brown, M., Solar, G.S., 1998. Shear-zone systems and melts: feedback relations and self-organization in orogenic belts. J. Struct. Geol. 20, 211-227.

Brown, M., Korhonen, F.J., Siddoway, C.S., 2011. Organizing melt flow through the crust. the mineralogical society of America. Elements 7, 261-266.

Carvalho, B.B., Sawyer, E.W., Janasi, V.A., 2016. Crustal reworking in a shear zone: transformation of metagranite to migmatite. J. Metamorph. Geol. http:/, dx.doi.org/10.1111/jmg.12180,

Cemens, Wall, 1981. Origin and crystallization of some peraluminous (S-type) granitic magmas. Can. Mineral. 19, 111-131.

Collins, W.J. Sawyer, E.W., 1996. Pervasive granitoid magma transfer through the lower-middle crust during non-coaxial compressional deformation. J. Metamorph. Geol. 14, 565-579,

Corvino, A.F., Pretorius, L.E., 2013. Uraniferous leucogranites south of Ida dome, central Damara belt, Namibia: morphology, distribution and mineralization. J. Afr. Earth Sci. 80, 60-73. http://dx.doi.org/10.1016/j.afrearsci.2013.01.003.

Davidson, C., Schmid, S.M., Hollister, LS., 1994. Role of melt during deformation in the deep crust. Terra Nova 6, 133-142.

Diener, J.F., White, R.W., Hudson, T.J., 2014. Melt production, redistribution and accumulation in mid-crustal source rocks, with implications for crustal-scale melt transfer. Lithos 200, 212-225.

Dieterich, J.H., 1969. Origin of cleavage in folded rocks. Am. J. Sci. 267, 155-165.

Druguet, E., Hutton, D.H.W., 1998. Syntectonic anatexis and magmatism in a midcrustal transpressional shear zone: an example from the Hercynian rocks of the eastern Pyrenees. J. Struct. Geol. 20, 905-916.

Etheridge, M.A., Wall, V.J., Cox, S.F., Vernon, M.H., 1984. High fluid pressures during regional metamorphism and deformation: implications for mass transport and deformation mechanism. I. Geophys. Res. 100, 4344-4358.

Goscombe, B., Hand, M., Gray, D., 2003. Structure of the Kaoko Belt, Namibia: progressive evolution of a dassic transpressional orogen. ]. Struct. Geol. 25 , $1049-1081$.

Hall, D., Kisters, A., 2012. The stabilization of self-organized leucogranite networks - implications for melt segregation and far-field melt-transfer in the continental crust. Earth Planet. Sci. Lett. 355-356, 1-12. http://dx.doi.org/10.1016 j.epsl.2012.08.033.

Hall, D., Kisters, A., 2016. From steep feeders to tabular plutons - emplacement controls of syntectonic granitoid plutons in the Damara Belt, Namibia. J. Afr. Earth Sci. 113, 51-64. http://dx.doi.org/10.1016/j.jafrearsci.2015.10.005.

Hand, M. Dirks, P.H.G.M. 1992. The influence of deformation on the formation of axial-planar leucosomes and the segregation of small melt bodies within the migmatitic Napperby Gneiss, central Australia. J. Struct. Geol. 14, 591-604. Hawkesworth, C.J., Gledhill, A.R., Roddick, J.C., Miller, R.M.C.G., Kröner, A., 1983. Rb$\mathrm{Sr}$ and $40 \mathrm{Ar} / 39 \mathrm{Ar}$ studies bearing on models for the thermal evolution of the Damara Belt, Namibia. In: Miller, R.M.C.G. (Ed.), Evolution of the Damara Orogen, Geological Society of South Africa. Special Publications 11, pp. 323-338.

Hoffman, P.F. Hawkins, D.R., Isachsen, C.E., Bowring, S.A., 1996. Precise U-Pb zircon ages for early damaran magmatism in the summas mountains and welwitschia inlier, northern Damara belt, Namibia. Commun. Geol. Surv. Namib. 11, 47-52. Hollister, L.S., Crawford, M.L., 1986. Melt-enhanced deformation: a major tectonic process. Geology 14, 558-561.

Hudleston, P.J., Treagus, S.H., 2010. Information from folds: a review. J. Struct. Geol, $32,2042-2071$.

Ismat, Z., 2015. What can the dihedral angle of conjugate faults tell us? J. Struct. Geol. 73, 97-113.

Jacob, R.E., 1974. Geology and Metamorphic Petrology of Part of The Damaran Orogen Along The Lower Swakop River, South West Africa. University of Cape Town, Chamber of Mines: Precambrian Research Unit Bulletin 17.

Johannes, W., 1984. Beginning of melting in the granite system Qz-Or-Ab-An-H2O. Contrib. Mineral. Petrol. 86, 264-273.

Jung, S., 2000. High-temperature, low/medium-pressure dockwise P-T paths and melting in the development of regional migmatites: the role of crustal thickening and repeated plutonism. Geol. J. 35, 345-359.

Jung, S., Mezger, K., 2003. Petrology of basement-dominated terranes: I. Regional metamorphic T- $t$ path from U-Pb monazite and Sm-Nd garnet geochronology (Central Damara orogen, Namibia). Chem. Geol. 198, 223-247. http://dx.doi.org/ $10.1016 /$ S0009-2541(03)00037-8.

Jurewicz, S.R., Watson, E.B., 1984. Distribution of partial melt in a felsic system: the importance of surface energy. Contrib. Mineral. Petrol. 85, 125-129.

Kisters, A.F.M., Jordaan, L.S., Neumaier, K., 2004. Thrust-related dome structures in the Karibib district and the origin of orthogonal fabric domains in the south Central Zone of the Pan-African Damara belt, Namibia. Precambrian Res. 133. 283-303.

Kisters, A.F.M., Ward, R.A., Anthonissen, C.., Vietze, M.E., 2009. Melt segregation and far-field melt transfer in the mid-crust. J. Geol. Soc. Lond. 166, 905-918. http://dx.doi.org/10.1144/0016-76492009-012.

Kisters, A.F.M., Vietze, M.E., Buick, I., 2012. Deformation of the stinkbank pluton and implications for the correlation of tectonometamorphic episodes in the PanAfrican Damara belt. South Afr. J. Geol. 115, 309-326. http://dx.doi.org/ 10.2113/gssajg.115.3.309.

Longridge, L., Gibson, R.L., Kinnaird, J.A., 2011. Constraining the timing of deformation in the southwestem central zone of the Damara belt, Namibia. J. Geol. Soc. Lond. Special Publ. 357, 107-135. http://dx.doi.org/10.1144/SP357.7.

Longridge, L., 2012. Tectonothermal evolution of the southwestern central zone, Damara belt, Namibia. Unpublished PhD thesis. University of the Witwatersrand, Johannesburg, South Africa.

McCaig, A.M., Wayne, D.M., Rosenbaum, J.M., 2000. Fluid expulsion and dilatancy pumping during thrusting in the Pyrenees: $\mathrm{Pb}$ and $\mathrm{Sr}$ isotope evidence. Geol. Soc. Am. Bull. 112, 1199-1208.

McDermott, F. Harris, N.B.W. Hawkesworth, C.J.1996. Geochemical constraints on crustal anatexis: a case study from the Pan-African granitoids of Namibia. Contrib. Mineral. Petrol. 123, 406-423.

Meneghini, F., Kisters, A., Buick, I., Fagereng, A., 2014. Fingerprints of late Neoproterozoic ridge subduction in the Pan-African Damara belt, Namibia. Geology 42, 903-906. http://dx.doi.org/10.1130/G35932.1.

Miller, C.F., Furbish, D.J., Walker, B.A., Claiborne, LL., Koteas, G.C., Bleick, H.A., Miller, J.S., 2011. Growth of plutons by incremental emplacement of sheets in crystal-rich host: evidence from Miocene intrusions of the Colorado River region, Nevada, USA. Tectonophysics 500, 65-77.

Miller, R.M.C.G., 1983. The Pan-African Damara orogen of south west Africa/ Namibia. In: Miller, R.McG. (Ed.), Evolution of the Damara Orogen. Geological Society of South Africa. Special Publication 11, pp. 431-515.

Miller, R.M.C.G., 2008. The Geology of Namibia. In: Neoproterozoic to Lower Palaeozoic, vol. 2. Geological Survey of Namibia, Windhoek.

Morfin, S., Sawyer, E.W., Bandyayera, D., 2013. Large volumes of anatectic melt restrained in granulite facies migmatites: an injection complex in northern Quebec. Lithos 168-169, 200-218. http://dx.doi.org/10.1016/ j.lithos.2013.02.007.

Nex, P.A.M., Kinnaird, J.A., Oliver, G.J.H., 2001. Petrology, geochemistry and uranium mineralisation of post-collisional magmatism around Goanikontes, southern Central Zone, Damaran Orogen, Namibia. J. Afr. Earth Sci. 33, 481-502

Oliver, G.J.H., 1994. Mid-crustal detachment and domes in the central zone of the Damara orogen, Namibia. J. Afr. Earth Sci. 19, 331-344 doi: 0899-5362(95) 00032-1.

Poli, L.C., Oliver, G.J.H., 2001. Constrictional deformation in the central zone of the Damara orogen. Namibia. J Afr. Earth Sci. 33, 303-321 doi: 0899-5362(01).

Ramsay, J.G., 1967. Folding and Fracturing of Rocks. McGraw Hill, New York.

Reichardt, H., Weinberg, R.F., 2012. The dike swarm of the Karakoram shear zone, Ladakh, NW India: Linking granite source to batholith. Geol. Soc. Am. Bull. 124, 89-103.

Rivalta, E., Taisne, B., Bunger, A.P., Katz, R.F., 2015. A review of mechanical models of dike propagation: schools of thought, results and future directions. Tectonophysics $638,1-42$

Rosenberg, C.L., Handy, M.R., 2001. Mechanisms and orientation of melt segregation paths during pure shearing of a partially molten rock analog (norcamphor-benzamide). J. Struct. Geol. 23, 1917-1932. 
T. Kruger, A. Kisters / Journal of Structural Geology 89 (2016) 1-18

Rosenberg, C.L, Handy, M.R., 2005. Experimental deformation of partially melted granite revisited: implications for the continental crust. J. Metamorph. Geol. 23 . 19-28.

Rubin, A.M., 1993. Dikes vs, diapirs in viscoelastic rock. Earth Planet. Sci. Lett. 119, 641-659.

Rushmer, T., 1995. An experimental deformation study of partially molten amphibolite: application to low-melt fraction segregation. J. Geophys. Res. 100 , $15681-15695$.

Sawyer, E.W., 1994. Melt segregation in the continental crust. Geology 22. 1019-1022.

Sawyer, E.W., 1998. Formation and evolution of granite magmas during crustal reworking: the significance of diatexites. J. Petrol. 39, 1147-1167.

Sawyer, E.W. 2000. Grain-scale and outcrop-scale distribution and movement of melt in a crystallising granite. Geol. Soc. Am. Special Pap. 350, 73-85.

Sawyer, E.W., 2008. Atlas of Migmatites. The Canadian Mineralogist. Special Publication 9.

Sawyer, E.W., 2014. The inception and growth of leucosomes: microstructure at the start of melt segregation in migmatites. J. Metamorph. Geol. 32, 695-712.

Sibson, R.H., 1996. Structural permeability of fluid-driven fault-fracture meshes. J. Struct. Geol. 18, 1031-1042. http://dx.doi.org/10.1016/0191-8141(96)00032-6.

Sibson, R.H., Scott, J., 1998. Stress/fault controls on the containment and release of overpressured fluids: examples from gold-quartz vein systems in Juneau, Alaska; Victoria, Australia and Otago, New Zealand. Ore Geol. Rev. 13, 293-306. Alaska: Victoria, Australia and Otago, New Zealand.
http://dx.doi.org/10.1016/S0169-1368(97)00023-1.

Smith, D.A.M., 1965. The geology of the area around the khan and Swakop rivers in south west africa. Mem. Geol. Surv. S. Afr. 3.

Soesoo, A., Bons, P.D., 2014. From migmatites to plutons: power law relationships in the evolution of magmatic bodies. Pure Appl. Geophys. 172, 1787-1801. http:// dx.doi.org/10.1007/s00024-014-0995-4.

Stanistreet, I.G., Kukla, P.A., Henry, G., 1991. Sedimentary basinal responses to a late precambrian wilson cycle: the Damara orogen and Nama Foreland, Namibia. J. Afr. Earth Sci. 13, 141-156.

Symington, N.J., Weinberg, R.F., Hasalová, P., Wolfram, LC., Raveggi, M. Armstrong, R.A., 2014. Multiple intrusions and remelting-remobilization events in a magmatic arc: the St. Peter Suite, South Australia. Geol. Soc. Am. Bull. 126
1200-1218. http://dx.doi.org/10.1130/B30975.1

Vanderhaeghe, O., 1999. Pervasive melt migration from migmatites to leucogranite in the Shuswap metamorphic core complex, Canada: control of regional deformation. Tectonophysics $312,35-55$.

Van der Molen, I., Paterson, M.S., 1979. Experimental deformation of partiallymelted granite. Contrib. Mineral. Petrol. 70, 299-318.

Vernon, R.H., Paterson, S.R., 2001. Axial-surface leucosomes in anatectic migmatites. Tectonophysics 335, 183-192.

Vigneresse, J.L, 1995. Control of granite emplacement by regional deformation. Tectonophysics 249, 173-186.

Vigneresse, J.L., Barbey, P., Cuney, M., 1996. Rheological transitions during partial melting and crystallization with application to felsic magma segregation and transfer. J. Petrol, 37, 1579-1600.

Ward, R., Stevens, G., Kisters, A., 2008. Fluid and deformation induced partial melting and melt volumes in low-temperature granulite-facies metasediments, Damara Belt, Namibia. Lithos 105, 253-271. http://dx.doi.org/10.1016/ j.lithos.2008.04.001.

Weinberg, R.F., 1996. Ascent mechanism of felsic magmas: news and views. Earth Environ. Sci. Trans. R. Soc. Edinb. 87, 95-103.

Weinberg, R.F., 1999. Mesoscale pervasive felsic magma migration: alternatives to dyking. Lithos $46,393-410$

Weinberg, R.F., Searle, M.P. 1998. The Pangong Injection Complex, Indian Karakoram: a case of pervasive granite flow through hot viscous crust.J. Geol. Soc. Lond. 155, 883-891.

Weinberg, RF., Mark, G., 2008. Magma migration, folding, and disaggregation of migmatites in the karakoram shear zone, Ladakh, NW India. Geol. Soc. Am. Bull. 120, 994-1009.

Weinberg, R.F., Mark, G., Reichardt, H., 2009. Magma ponding in the Karakoram shear zone, Ladakh, NW India. Geol. Soc. Am. Bull. 121, 278-285. http:// dx.doi.org/10.1130/B2635.8.1.

Weinberg, R.F., Veveakis, E., Regenauer-Lieb, K., 2015. Compaction-driven melt segregation in migmatites. Geology $43,471-474$.

Wickham, S.M., 1987. The segregation and emplacement of granitic magma. J. Geol. Soc. Lond. 144, 281-297. 


\section{Chapter 4: Conclusion}

\subsection{Synopsis and conclusion}

The structural study of these leucogranites and the wall rock is important for exploration because it directly controls the orientation of the leucogranite network. The association between regional-scale folds, especially antiforms, particular wall-rock lithologies, leucogranite network geometry and the extent to which the magma has been fractionated provide useful indicators for exploration of leucogranite-hosted uranium deposits. In essence, the paper describes the structurally-controlled redistribution, associated deformation-driven fractionation and accumulation/emplacement of leucogranites in specific structural sites during regional deformation in this part of the $\mathrm{sCZ}$. Apart from the insights into the controls of magma transport and fractionation processes of granitic magmas, an understanding of these integrated processes is crucial for exploration and mining.

\subsection{Future work}

The present study has mainly addressed the processes of deformation-driven magma transport and redistribution. However, this part of the study was based on the detailed mapping of the regional geology, partly presented in figures 2, 3 and 4 of Kruger and Kisters (2016). The mapping undertaken in this project indicates (1) inconsistencies in the currently accepted and published tectonostratigraphic subdivision of the region (Smith, 1965; Jacob, 1974; Miller, 2008), that are (2) related to the presence of hitherto not identified structural breaks, namely the presence of earlier refolded nappes and later low-angle thrusts.

Thrust faults have been identified in the field and geochronological work (Kruger, unpubl.) on syn-tectonic granites suggest that multiple thrusting events occurred during progressive deformation of the sCZ. Nappe structures and duplexes of allochthonous units 
override an autochthonous footwall, of which the Holland's dome forms part. The presence of these thrusts and nappe structures is able to explain the excision and/or duplication of certain units and, in places, the clearly inverted stratigraphy. Large accumulations of granites have also been found along thrust zones strongly suggesting that thrusts are not only pathways for magma transfer, but they also localize strain and in that way lubricate the thrusts. This leaves room for investigation into the positive feedback mechanism between deformation, in this case thrusting, and magma transport in the mid- to lower crust. 


\section{References}

Bons, P., Arnold, J., Elburg, M., Kalda, J., Soesoo, A., van Milligen, B., 2004. Melt extraction and accumulation from partially molten rocks. Lithos 78, 25-42, doi: 10.1016/j.lithos.2004.04.041.

Brown, M., 2001. Orogeny, migmatites and leucogranites: a review. Journal of Earth System Science 110, 313-336.

Brown, M., 2007. Crustal melting and melt extraction, ascent and emplacement in orogens: mechanisms and consequences. Journal of the Geological Society 164, 709-730.

Brown, M., 2013. Granite: From genesis to emplacement. Geological Society of America Bulletin 125, 1079-1113.

Clemens, J.D., Mawer, C.K., 1992. Granitic magma transport by fracture propagation. Tectonophysics 204, 339-360.

Corvino, A.F., Pretorius, L.E., 2013. Uraniferous leucogranites south of Ida Dome, central Damara Belt, Namibia: Morphology, distribution and mineralization. Journal of African Earth Sciences 80, 60-73, doi: 10.1016/j.afrearsci.2013.01.003.

De Kock, G.S., Eglington, B., Armstrong, R.A., Hermer, R.E., Walraven, F. 2000. U-Pb and $\mathrm{Pb}-\mathrm{Pb}$ ages of the Naauwpoort Rhyolite, Kawakeup leptite and Okongava Diorite: implications for the onset of rifting and of orogenesis in the Damara Belt, Namibia. In: Miller, R.McG. (Ed.), Henno Martin Commemorative Volume. Communications of the Geological Survey of Namibia 12, 81-88.

Glazner, A.F., Bartley, J.M., Coleman, D.S., Gray, W., Taylor, R.Z., 2004. Are plutons assembled over millions of years by amalgamation from small magma chambers?. GSA today $14,4-12$.

Gray, D.R., Foster, D.A., Meert, J.G., Goscombe, B.D., Armstrong, R., Trouw, R.A.J., Passchier, C.W., 2008. A Damara orogen perspective on the assembly of southwestern Gondwana. Geological Society, London, Special Publications 294, 257-278.

Hall, D.J., Kisters, A.F.M., 2012. The stabilization of self-organised leucogranite networks Implications for melt segregation and far-field melt transfer in the continental crust. Earth and Planetary Science Letters 355-356, 1-12.

Hall, D., Kisters, A., 2016. From steep feeders to tabular plutons - Emplacement controls of syntectonic granitoid plutons in the Damara Belt, Namibia. Journal of African Earth Sciences 113, 51-64, doi: 10.1016/j.jafrearsci.2015.10.005. 
Jacob, R.E., 1974. Geology and metamorphic petrology of part of the Damaran Orogen along the lower Swakop River, South West Africa. University of Cape Town, Chamber of Mines: Precambrian Research Unit Bulletin 17.

Jung, S., 2000. High-temperature, low/medium-pressure clockwise P-T paths and melting in the development of regional migmatites: the role of crustal thickening and repeated plutonism. Geological Journal 35, 345-359.

Jung, S., Mezger, K., 2003. Petrology of basement-dominated terranes: I. Regional metamorphic $\mathrm{T}-t$ path from $\mathrm{U}-\mathrm{Pb}$ monazite and $\mathrm{Sm}-\mathrm{Nd}$ garnet geochronology (Central Damara orogen, Namibia). Chemical Geology 198, 223-247, doi: 10.1016/S00092541(03)00037-8.

Kinnaird, J.A., Nex, P.A.M., 2007. A review of geological controls on uranium mineralisation in sheeted leucogranites within the Damara Orogen, Namibia. Applied Earth Science 116, $68-85$.

Kisters, A.F.M., Jordaan, L.S., Neumaier, K., 2004. Thrust-related dome structures in the Karibib district and the origin of orthogonal fabric domains in the south Central Zone of the Pna-African Damara belt, Namibia. Precambrian Research 133, 283-303.

Kisters, A.F.M., Ward, R.A., Anthonissen, C.J., Vietze, M.E., 2009. Melt segregation and farfield melt transfer in the mid-crust. Journal of the Geological Society, London 166, $905-$ 918.

Kisters, A.F.M., Vietze, M.E., Buick, I., 2012. Deformation and age of the Stinkbank Pluton and implications for the correlation of tectonometamorphic episodes in the Pan-African Damara belt. South African Journal of Geology 115, 309-326, doi: 10.2113/gssajg.115.3.309.

Longridge, L., Gibson, R.L., Kinnaird, J.A., 2011. Constraining the timing of deformation in the southwestern Central Zone of the Damara Belt, Namibia. Journal of the Geological Society, London, Special Publications 357, 107-135, doi: 10.1144/SP357.7.

Longridge, L., 2012. Tectonothermal Evolution of the southwestern Central Zone, Damara Belt, Namibia. Unpublished $\mathrm{PhD}$ thesis, University of the Witwatersrand, Johannesburg, South Africa.

Masberg, H.P., Hoffer, E., Hoernes, S., 1992. Microfabrics indicating granulite-facies metamorphism in the low-pressure central Damara Orogen, Namibia. Precambrian Research 55, 243-257 
Massey, M.A., Moecher, D.P., 2013. Transpression, extrusion, partitioning, and lateral escape in the middle crust: Significance of structures, fabrics, and kinematics in the Bronson Hill zone, southern New England, USA. Journal of Structural Geology 55, 62-78.

Meneghini, F., Kisters, A., Buick, I., Fagereng, Á., 2014, Fingerprints of late Neoproterozoic ridge subduction in the Pan-African Damara belt, Namibia: Geology 42, 903-906, doi: 10.1130/G35932.1.

McDermott, F., Harris, N.B.W., Hawkesworth, C.J., 1996. Geochemical constraints on crustal anatexis: a case study from the Pan-African granitoids of Namibia. Contributions to Mineralogy and Petrology 123, 406-423.

Miller, R.McG., 1983. The Pan-African Damara Orogen of South West Africa/Namibia. In: Miller, R.McG. (Ed.) Evolution of the Damara Orogen. Geological Society of South Africa, Special Publication 11, 431-515.

Miller, R.McG., 2008. The geology of Namibia, Volume 2: Neoproterozoic to lower Palaeozoic. Windhoek, Geological Survey of Namibia.

Nex, P.A.M., Kinnaird, J.A., Oliver, G.J.H., 2001. Petrology, geochemistry and uranium mineralisation of post-collisional magmatism around Goanikontes, southern Central Zone, Damaran Orogen, Namibia. Journal of African Earth Sciences 33, 481-502.

Oliver, G.J.H., 1994. Mid-crustal detachment and domes in the central zone of the Damara orogen, Namibia. Journal of African Earth Sciences 19, 331-344, doi: 08995362(95)00032-1.

Petford, N., Lister, J.R., Kerr, R.C., 1994. The ascent of felsic magmas in dykes. Lithos 32, 161-168.

Petford, N., Cruden, A.R., McCaffrey, K.J.W., Vigneresse, J.L., 2000. Granite magma formation, transport and emplacement in the Earth's crust. Nature 408, 669-673.

Poli, L.C., Oliver, G.J.H., 2001. Constrictional deformation in the Central Zone of the Damara Orogen, Namibia. Journal of African Earth Sciences 33, 303-321, doi: 0899-5362(01).

Rosenberg, C.L., Handy, M.R., 2005. Experimental deformation of partially melted granite revisited: implications for the continental crust. Journal of Metamorphic Geology 23, 1928.

Sawyer, E.W., 2014. The inception and growth of leucosomes: microstructure at the start of melt segregation in migmatites. Journal of Metamorphic Geology 32, 695-712. 
Sleep, N.H., 1988. Tapping of melt by veins and dikes. Journal of Geophysical Research: Solid Earth 93, 10255-10272.

Smith, D.A.M., 1965. The geology around the Khan and Swakop Rivers in South West Africa. Memoirs of the Geological Survey of South Africa, South West Africa Series 3, 113.

Stanistreet, I.G., Kukla, P.A., Henry, G., 1991. Sedimentary basinal responses to a Late Precambrian Wilson Cycle: the Damara Orogen and Nama Foreland, Namibia. Journal of African Earth Sciences 13, 141-156.

Ward, R., Stevens, G., Kisters, A., 2008. Fluid and deformation induced partial melting and melt volumes in low-temperature granulite-facies metasediments, Damara Belt, Namibia. Lithos 105, 253-271, doi: 10.1016/j.lithos.2008.04.001.

Weertman, J., 1971. Theory of water-filled crevasses in glaciers applied to vertical magma transport beneath oceanic ridges. Journal of Geophysical Research 76, 1171-1183.

Weinberg, R.F., Regenauer-Lieb, K., 2010. Ductile fractures and magma migration from source. Geology 38, 363-366.

World-nuclear.org., 2016. World Uranium Mining Production - World Nuclear Association. [online] Available at: http://www.world-nuclear.org/information-library/nuclear-fuelcycle/mining-of-uranium/world-uranium-mining-production.aspx [Accessed 10 May 2016]. 


\section{Appendix A: Research Outputs}

Peer-reviewed article:

Kruger, T.M. \& Kisters, A.F.M., 2016. Magma accumulation and segregation during regional-scale folding: the Holland's dome granite injection complex, Damara belt, Namibia. Journal of Structural Geology 89, 1-18, doi:10.1016/j.jsg.2016.05.002

Conference Abstract:

Kruger, T.M. \& Kisters, A.F.M., August 2015. Oral Presentation: Regional-scale folding and magma extraction: geometry and origin of $\mathrm{km}$-scale leucogranite networks in the Holland's dome of the Damara Belt in Namibia. Granulites \& granulites 2015. 